University of Louisville

ThinkIR: The University of Louisville's Institutional Repository

1947

\title{
The development of an ethocel automobile touch-up lacquer and a suitable sanding surfacer: II. a study of the physiological effect of color using the Munsell Color Notation.
}

Thaddeus Andrew Peake 1919-1999

University of Louisville

Follow this and additional works at: https://ir.library.louisville.edu/etd

Part of the Chemical Engineering Commons

\section{Recommended Citation}

Peake, Thaddeus Andrew 1919-1999, "The development of an ethocel automobile touch-up lacquer and a suitable sanding surfacer : Il. a study of the physiological effect of color using the Munsell Color Notation." (1947). Electronic Theses and Dissertations. Paper 2123.

https://doi.org/10.18297/etd/2123

This Master's Thesis is brought to you for free and open access by ThinkIR: The University of Louisville's Institutional Repository. It has been accepted for inclusion in Electronic Theses and Dissertations by an authorized administrator of ThinkIR: The University of Louisville's Institutional Repository. This title appears here courtesy of the author, who has retained all other copyrights. For more information, please contact thinkir@louisville.edu. 


\title{
varvaserx of Lovrovrus:
}

PART I

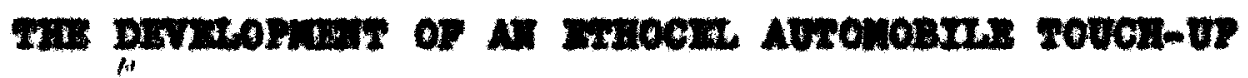

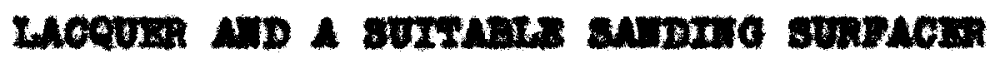

\author{
Pant II

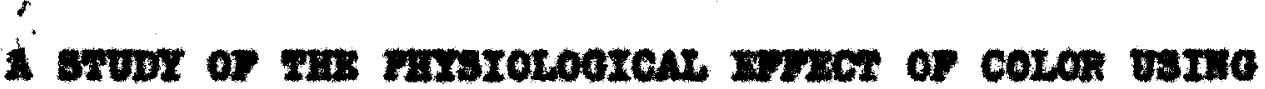

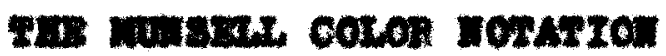

\author{
A rones. \\ submitted to the proulty \\ of the orvedunte sehool \\ of the Eatreralty of Loulovilie \\ in Fartiel Fole12inont \\ of the Requirement: \\ for the Degree of

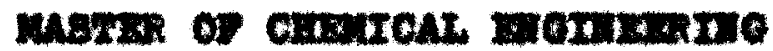 \\ Dopartant of Chonteal mefneering \\ Thaddeus Androw Podke, Dr.
}

apteniber. 1947 


\section{UNIVERSITY}

LIBRARIES

This PDF document is a scanned copy of a paper manuscript housed in the University of Louisville (UofL) Libraries. The quality of this reproduction is greatly dependent upon the condition of the original paper copy. Indistinct print and poor quality illustrations are a direct reflection of the quality of materials that are available for scanning. The UofL Libraries greatly appreciates any better copies that can be made available for replacement scans. 


\section{PART I}

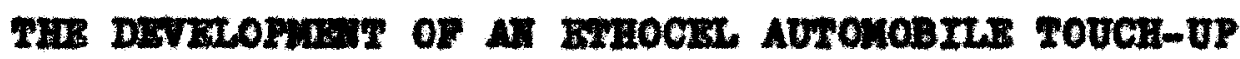

LACQUER AID A SUTHABL SATDme SURFACER

PART II

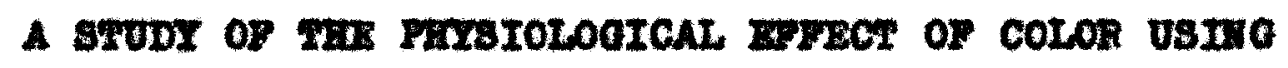
THe norstur coton nOsATIOA

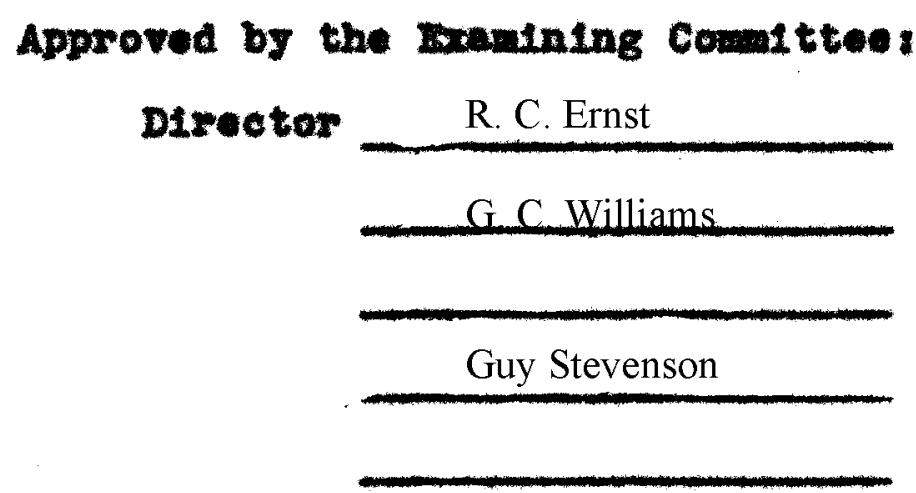




\section{AGxourEDangur}

The author wisheg to soknowledge

the kind aselstance and holprul guldanos

or Dx. R. O. Ernot,

who direeted this revearoh. 


\section{TABTE of COATHAS}

\section{PART I}

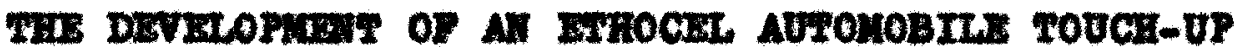

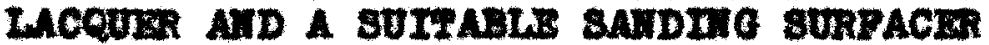

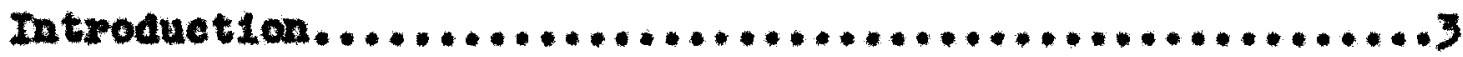

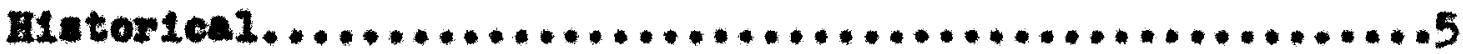

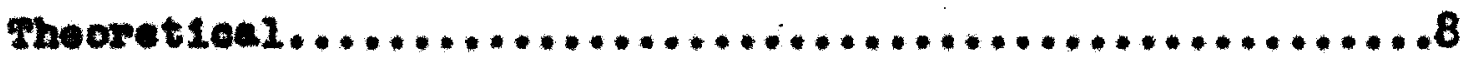

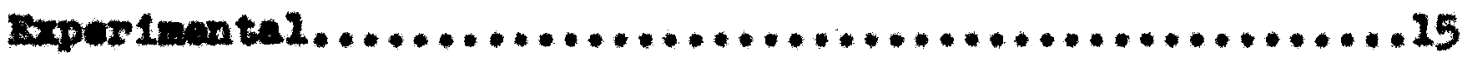

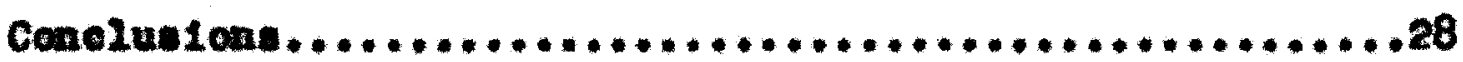

\section{PART II}

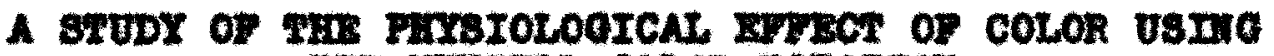

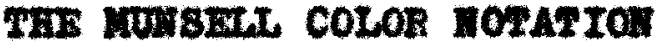

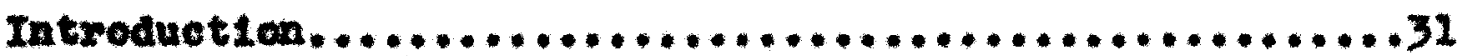

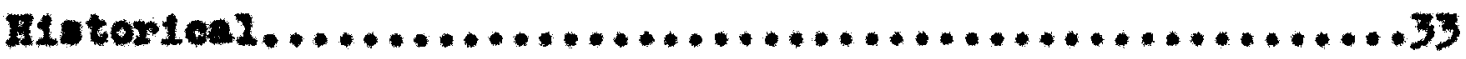

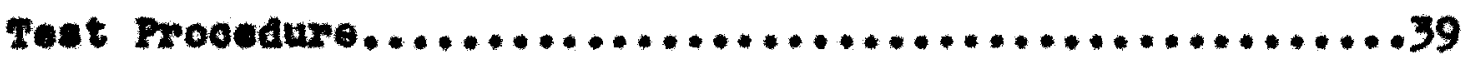

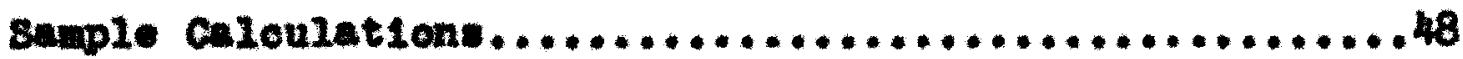

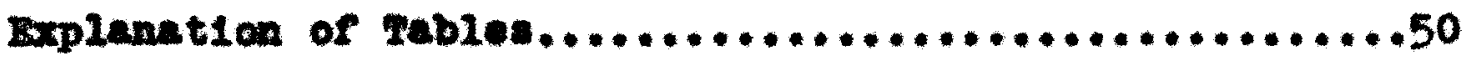

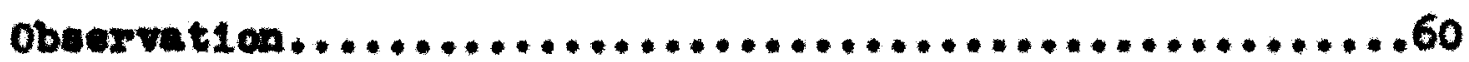

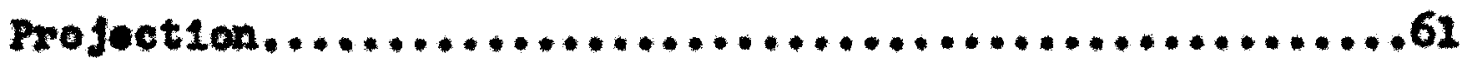

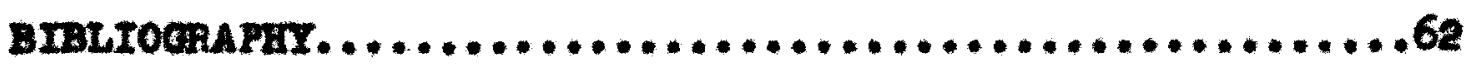

VIx.........................................63 


\section{Lren of raths}

Pans I

\section{TADTB}

Ron

I. Surfecor Formulation Ho. 6e.................20

II. Surfacer pormulat1on wo. 179...............21

III. Top Coat Formulationa....................25

IV. Roend to of Teate...........................26

PART IT

I. Individual Apulyula sheet shovins Muneell Yeliov-Red Chip Arrangement........... H2

II. Indiviaual Andigsis sheet shoving henesll Red Chip Arrangement...............43

III. Indiviaunl Amalyels Shoet shoving Muncell Oreen Chip Arrengenent...............44

IV. Cenverting Danter Rerlectometer Values to the Eureau of atendards color valueo................................45

V. Neseuroments of Due, Value and Chrom Difference Betimates betwoen munsell

Color chipe for 5 groen....................46

7I. Honeuremente of Hue, Velue and Chrome Difforence Butimates botveen Munsell Color Ohlpe for 7.5 orem standard...........47

VII. Test Reavite (MHLOW-RED) ..................52

vrIx. Toet nesulte (RED).......................56

IX. Tent Results (Conmin) ......................58

x. Color Change Frororence...................61 


\section{LIST OF FIOURES}

FIOUREB

PAOE

I. Soale of Munsell values on the Heutral Axis...37

II. Hex, Velue and Chroses The1r Relation

to Each other............................38 
$\operatorname{ran} t$

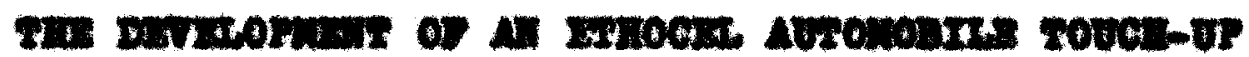

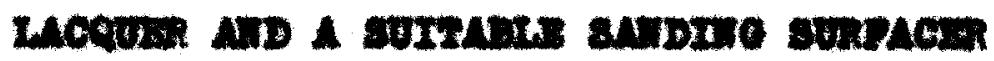

Aneruor 
The object of th1s research 1s to develop an ethocel autonob11. touch-up Iaequer and a satisfactory ethoes sanding aurfecer. The researoh vas condueted by solecting - number of comarelally arallable reolns and plastlelsors and varging the por conte realh, plastieler, thocel and solvent so es to obtain the desired qualitios in the rinished conting. In 1942, Bnet, Greef and the outhor did some research on the problem and dovelopod a surfacer and an cutomob110 1sequer 10.62 (Table I) that exhiblted good properties but that was too hlgh in price. The present rewearch 1s a continuation of this earlior etudy. Plgmentation or the elear lecquere used in this study presented a "Grinding problem." Anothor difriculty wa enoountered in obtaining adhesion between the Ieequer f1Im and a steel panel.

Both the grey sanding surfacer to be used in conJunction vith the black othoed automoblie touch-up lecquer and the Inoquer 1 twelf vere formulated ccoording to the sans procedure.

The research leading to the dovelopment of a setis- 
fectory ethocel eutomoblie touch-up lacquer nocesaltated a rery thorough investigation of wany leoquor rav materials. The use of a calroble solvent retio ves exrived at after onoountering moh deficulty in spraying: but by varying proportions of toluol, othanol and butenol, this problen vas coupletely wolved.

Tho sam difrioulty was oneountored in the Iecenor formulation as vas oncountered in the surfacer formiletion with reapect to the solvent ratio.

There were two suraeer pigant oomblnstions used throughout thie roseareh. The riret combination vas that of surracer Dormaletion No. 62 (Table I), and the cecond combinstion, that of surfacer pormalation No. 179 (rable II). The grey sanding surfecer shows great posstbility In the commorelal fiela bocause it oxhtbite properties that are acoond to no eurrecor on the market todny, In ethocel automob110 touch-up Iacquer v111 not reach the warket with the prosont rosins that are avaliable, and in the future it 10 rocommended that no rurther vork be cons on a touch-up leequer unt1l more sultable realne are coveloped. 
PARY II

A STODI of WE PHYsioloetcal Emect or colon UBInO THE monser. cotor moratrom

\section{Araner}


The purpose of this researob vas to dotermine the change in shade that vas preforred by a oustomer if the favorite color vore to change becaune of age. This change is one thet has been not1ced as a proteotive coatIng agen and changes from one uhade of $a c 010 \mathrm{r}$ to an entirely different whade. Inowing the proforence of a oustower, this change mey be made plensing or dinpleaning depending upon the formulation of the bese color. This study ut121zed the Muneell Color Motation (13) that 1. deseribed in the thesis. Tho observer's hue, velue and chrom preferences vere doteratined by a series of tente rully deseribed in the section on "rost procedure,"

It was concluded that all obeervers tend to choose a color that vill look best on son particuler object. Alwot everyone cleiming color-blindnes could distinguiah a difference in any two colore, therefore reaulte of test: vere not meterielly ohanged. Wrow the rindinge of one or two colore it is imposelble to forecest the results for a thind color.

In all eaces the bluer hue was preferred, but to - greater extent by vomen, expectelly in the case of red and groen. 
In 112 cases vomen profer thetr celore to be

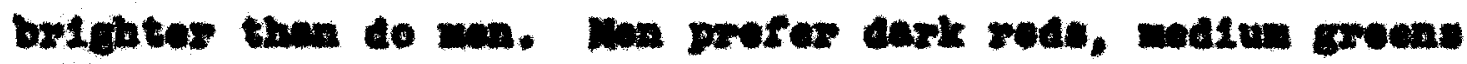
and light relion rode.

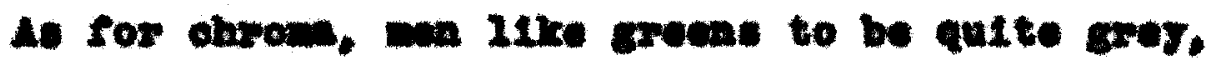
bet jellow mede to be well siturated. Vomen are juet the opposte. Both wen and romen, hownver, wat rods of strone ohrom. 


\section{PAnT I}

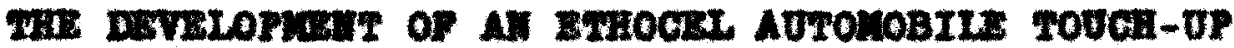

LACQUER AID A SUITABLE SAUDHO SURPACRR 
Inwopector 
The object of this rosearch is to develop an ethocel automob120 touch-up lecquer and a atiafectory othocel wanding ourracer.

Bthoeel is a oellulose ester resulting from the interaction of ethyl chloride and alkall celivione. It is manufaetured by the Dow Chomleal Conpany of Milend, Michigr. This cellulose derivative y1elds a greater volune of r11m-forming sollds per unit velght than any other coumorclal derivative, adding toughnese to a lecquer so vell es an unusual degres of flexiblitty. These are very revorable attributes then a matorial is being selected to be a con-tituent of a Inequer type protective conting.

Th1. research vas condueted by selecting a number of oomoreially avalleble rosins and plasticleers, and varyIng the porcents of rosin, plastleteor, othocel and solvent oo as to obtein tho dosired quelities in the finished conting. 
meronteat 
The first description of thocel and wothode for 1ta manufecture and proparation probebly appeered in 1905 in Nonstaherte fux chomie by sulde (1). Thore were many patento obtalned on the preparation of the other, som being those of breyfus (2) and Lenche (3). The blgh cost of wanracture provented the videspread industriel uce of this material unt11 reoent years. In 1936 ethocel ceased to be an Import and 1ts manufecture vas begun in this country. It 18 now on the warket at a cost that wakes it avaliable for Industrial use.

Ithocel is manufactured according to the classioal mothods for the manufacture of the cellulose ethers. Cellu1086 is converted into alkall cellulose by treatment vith strong equeous solutions or sodiun hydroxide. This alkel1 cellulose is alkyleted with such reagents a ethyl chloride or eulfate. To evold degeneration of the cellulose and of the eikylating agent, the alkylation is carried out vith very careful temperature control. When the reaction is completed, the reagent and the by-product: are seperated by vash1ng and by distilietion. By repeated vasing with wator, the purifiention of ethoeer is fimelig coupleted. 
Ethoeel way vary if propertios cocording to the

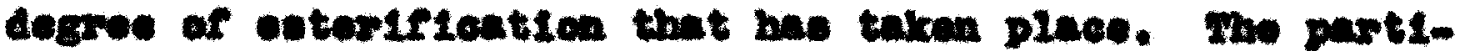
oulas type of othoed that we omployed in this otudy ves "Btundara Ethoed" baving a vimeovity or 10 to 50 centipolec. Thle wterial has an othosy eontent of 18.5 to 19.5 per eent. zthoes It a wite colld that in Ite powdored form resobles erretalitne sodiun chloples. It rosombles.

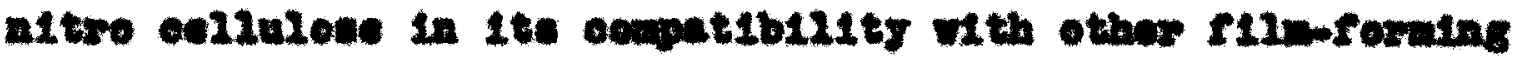

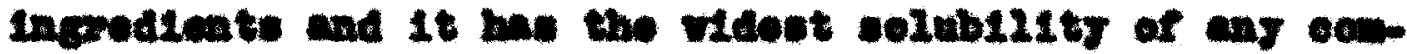

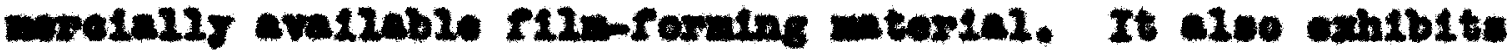

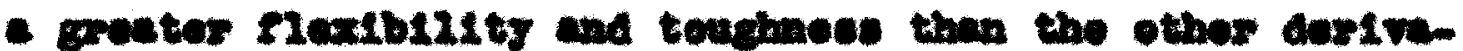

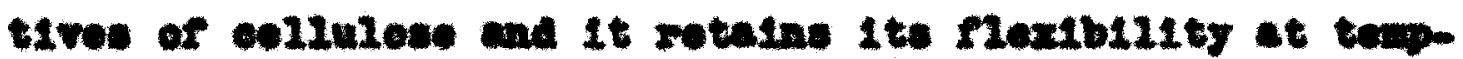
exatures as 10u at $-40^{\circ} \mathrm{C}$.

In 1942, Iraot, Gear and the author ald com

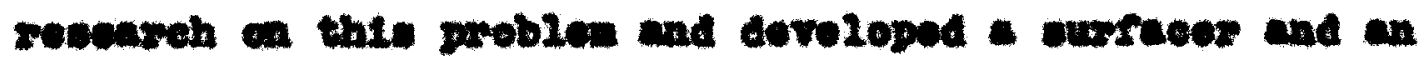
antowoblie 2eoquer No. 6e (Table I) thet onibited culteble proporties, but the pries wa too costzy. The prosent wewareh is a continuntica of the abow vork. 
Taxonaxtont 
Dopanding upen the purpose for inteh e 2loquor is

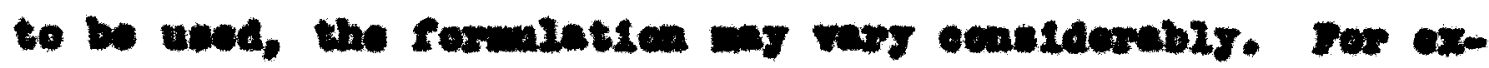

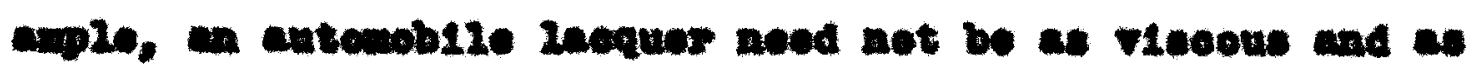

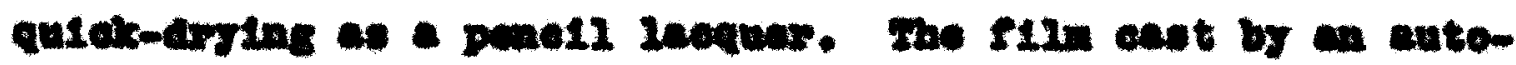
noblle Isequor unet bave a gratos bardnous, cohoston ase curbblity then any of the othor 2kequore in producticn toasy.

A Inequer wy be alvied into two distinet compo-

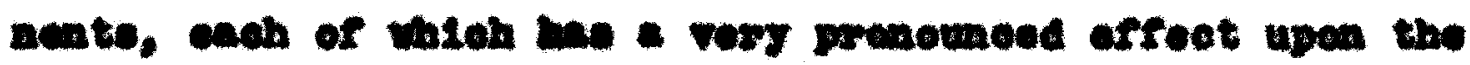
final proporties of the laguos.

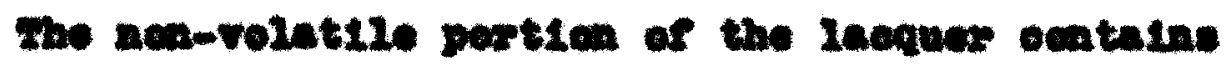
the film-roming cenotitugnts, and it is by vering thowe

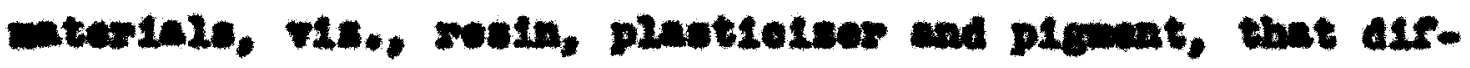

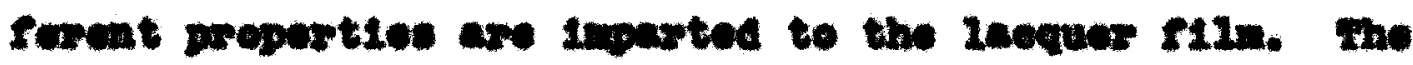

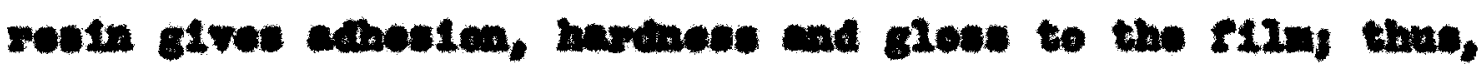
the type or the proportion of rouln ay import a varioty of

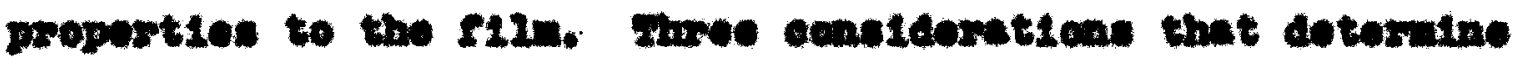

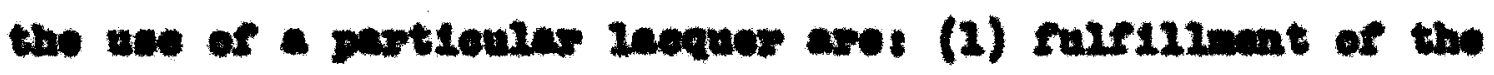
requirod physted propartios for the riIn (2) ocmpatibility Fth the other cenotitemets of the Inogen (3) oultoblilty of pite for ande an ecmpotitive markots. 
The plesticleor, elther ehomien or resin type, 1s used to give the film the required Plexibility. Plesti-

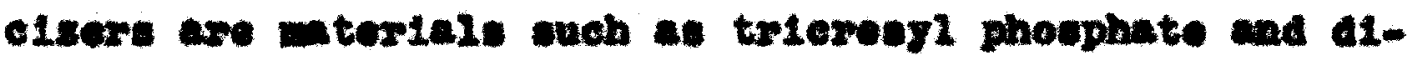
octylghthalete. In sow cases, the rosin used is a plasti-

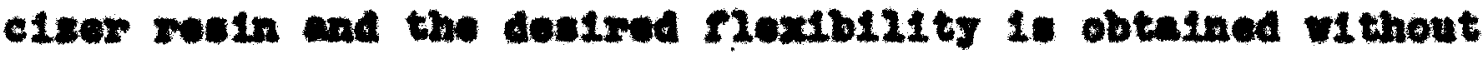
the use of a plestielsos an aneh.

PLgmente are used in Inequor for their docorative effeot and for their hiding pover. It in vory seldon that

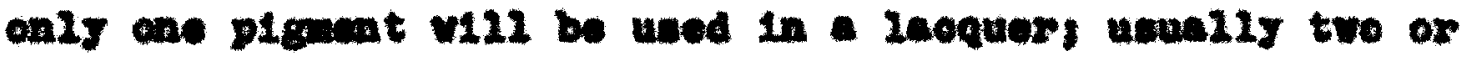
wore wre required to sohteve the dontred color and hlding

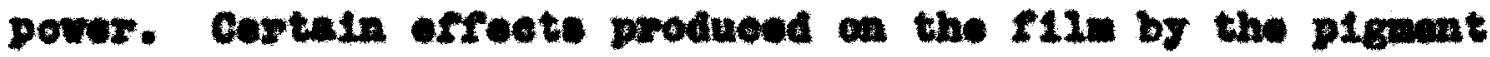
are: the riliting of plte, the increase of adnenton and the improvenent of corroulon resiotance.

The volut1le portion of a lequer opaciete of varlous comblaticas of volet1le solvente. Throe conditican that those colvents mut fulfili ares (1) ooupetibility ith al1 conotituents of the 2 ceguor (2) eveporetion that $\mathrm{W} 12$

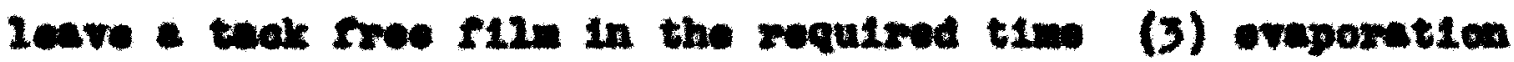
at a sate thet $\mathbf{w 1 1}$ not reault in ang undosirable orfoets upen the f1Im. If the colverte axe too voletile, acondensetion of moleture vill oscur, giving the P1Im a blublod 
effect. If the colvente ovaporate too o20v1y, there 112 be a toadeapr for the E1In to sag bafore it obtaine the InIt1al set. Striot adbarence to the above-mentionod conattions w111 reoult in a stisectory 111 . Plementation of the olear lecquer used in this etudy prosented a "grinding" problem. in erfort va rirot made to plemot the elear lecquer by the use of a ball w111, but this whod ald not prove satiaructory. In an effort to solve thie problem, Inequer chipe vere next used; and Wen the proper rooults wore not obtaingd, a dioporelen of carbon bleck, thook2, alcohol and toluol vat ued. The

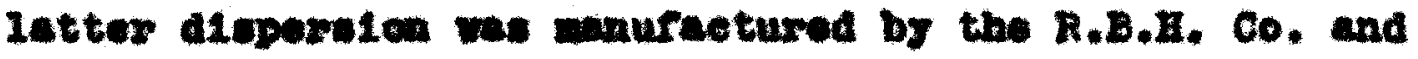
vas destgnated as Ren Dioperelon Ho. 9002. The compostion or Mall Dtopersion Io. 9002, which vorked very satiafaotor12y, aty be found in rable 1.

The rolloring section reveals the conditions necesenry for adhomion between the Iecquer f1In and a teel panel, wich for thic problow presented a spelal difficulty. 
Tho study of the conditions that bring about adhosion of a protective coating to a motal surface vith reIation to 1 to importanee in the formiation of a satiorectory oouting is we that bas recelved 11 the consteretion.

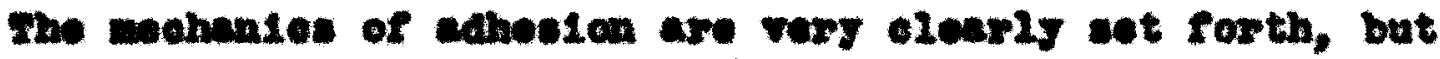
In only one reoorded ones $(4,5,6,7,8,9,20)$ have defindte

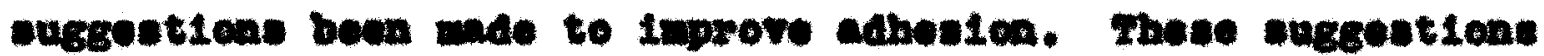
vore antionce in (4) add ore expleined as follow.

A. mtoriookins Fronowona

(I) those phenowen exiet bon the surrace of the netal has way ninute irregr10rit1es. Such o condition wy be brought ebout by and-biecting. otohing vith eete, or by the vine of any other. nothod that vil predues irreguinritios in the ourface. The fili is do ble to get doun into enal of these nan roceseses and by wo dolng, gain bettor adbostan to the metelile eurface.

(2) A F12 of extde, expencte, of phorphete 1. applied to the ourfece of the wotel and tis Iesquer fiIm colvores to it becaupe of the Irreguiar ourface that is produece.

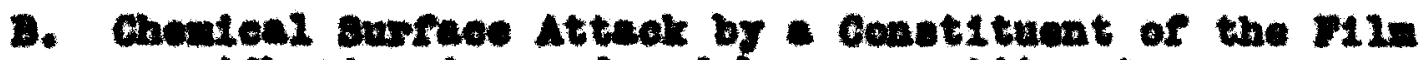

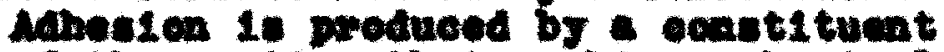
of the costing that somblese ohontent-

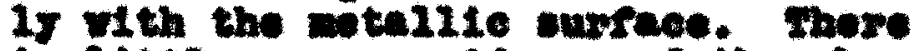
1. Lttis or no oridenes of the above

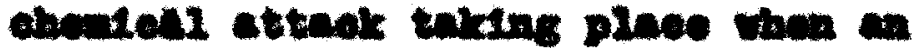




\section{orgence coeting is applied to otal11e awrees.}

\section{c. Maporption poros}

A proteotive costing aboring to a ntall1e curface is the wost importent and is the ont that doserves noot coneldoration. Dome difrieulty bes beca cheounterod in expletining tho defroment thoortes of ceseorptien and the complete explenntion I1es berand the eeepe of this tho1.1. The two wothods of chosion by this wethod ine as fol2ow.

(1) A veteriel that is imoin to bo hlehly broxbed una brought Into ecntaet with the wotalile eurrees is included in the formintien of the contIng. When the conting arios, can and of the wolecule is coboded in tho wtalile ourrece and the othor and Is cubouded in the Fil body. the giving the couting propor adboetcen.

(2) Then a obonteal group is fown thet 1. aboorbed readily by the weteli10 ourface. this group in ohentealiy rebeted oith cuituble oosting wetor1e1. Mon the centine is applied to the curreeo, the group to be abcorbed is a part of the coetine so It is aboorbed of before, inparting to the cooting ourfietent adiosica.

A reseaveh of literature an this subjoet rielded the rollowing eonolustons. It has boan found that carboxyl

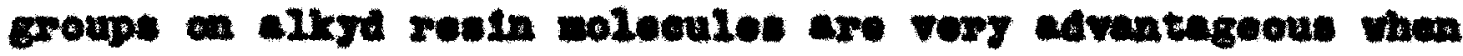




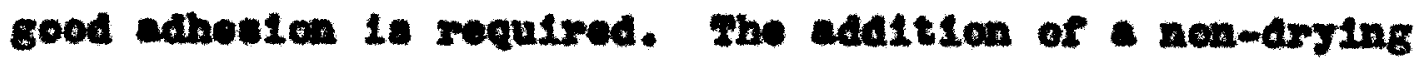
phthalete roein tends to perforw two dutles, anmil, plastlelaing the f12m and introducing poler croupe that wy ald in the edvorption of the matoriel to the metal surrece.

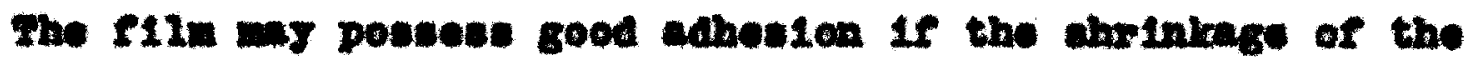
Iscquor is not too groat on arging. This uhrinkage tends

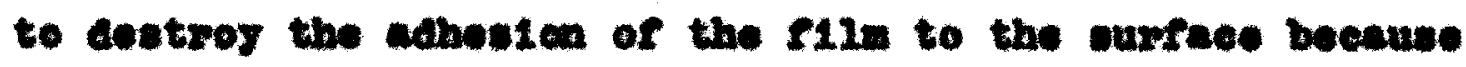
of the tromadoun fowces brought in to play.

VInyl ecotete and other ringl compounds vore wontloned as an ald in nking othyl collulose glwo and othor binding compounde. It is belleved, thorefowe, that vingl

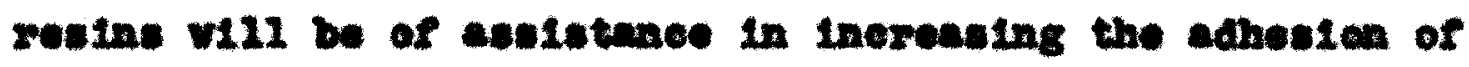
-thyl cellulose leceuore. For exuple, polyvinglchloride could be uned in the granular form and mon teken up vith methy kotone, it could be inoorporated into a lecauor.

It 1s of primapy importance thet the surfece to be coeted be thoroughy eleaned. This aleansing is beut acooplinbed by whing the ourfees ith eleobol or acotone,

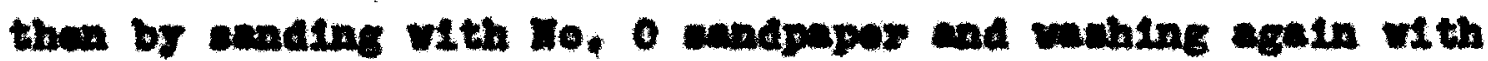
a solvant. 
expratmonat 
The groy waing ourtaces to be ubed in oonjunction with the bleck thoed automoblis touob-up Iecquor ves formuleted wecording to the same pooveure that was followed in the formulation of the 2nequer.

Thowe vore two awrece plgment combinntions uned throughout this rescuroh. The firet comblnation wat that of surfacer Powmintion no. 6e(reble I), and the second combination, that of surfeoor Porwulation mo. 179 (2able II). The reason for the use of the tro oombinations was that all poselbilities of unting the Wo. 62 combinutien in a vuecossful formiletion bad been oxheusted in previous vork $(11,12)$ and I0. 179 combination was ohowen in an erfort to secure a

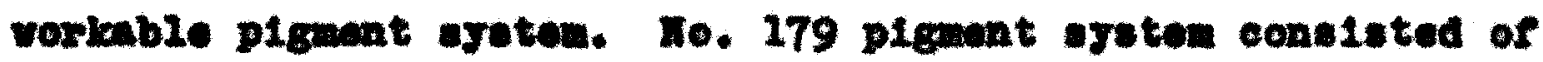
I1tanox B, Bargtee and Bonpotane.

Dexing thie reveavoh, the monity of comerelal rening ve investigated as poselble constituente for the ourfecer wth very 11ttle ouceses until the oll-modiried

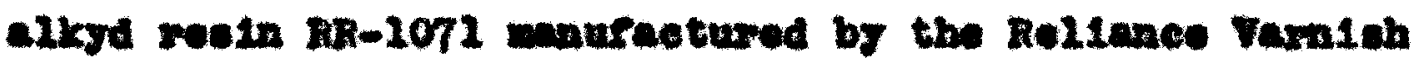
Coupany of Louleville, rentuok we used. RR-1071 used in the propostions show in suxracor Fonwulation No. 179 (rable II) Inparted to the 211 all proporties dosirable in a good 
sanding anwrager.

The poselbilities of velng other reoulty cthom oel in plee or 20 opo. wot vith 11 tele suecers. Whe highor

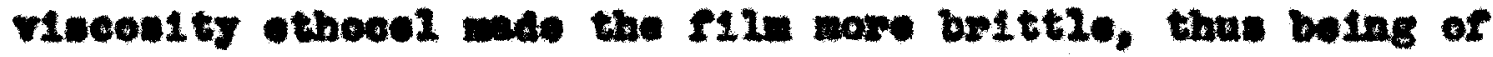

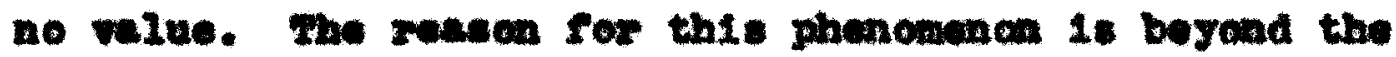
coope of this monowrah.

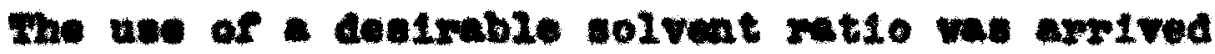

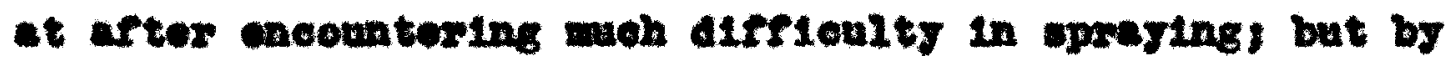
rarying the proportione of toluol, othoes and butanal, this problem wa comitery nolwoa.

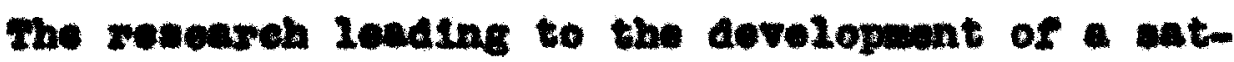

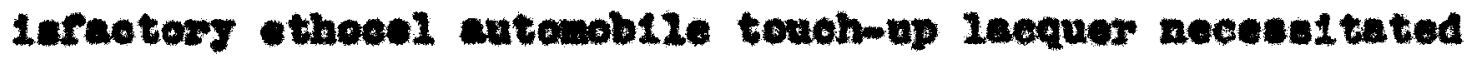
- Vory thorough investigation of many luequer rov wateriale. Plgumtation of the lacquer wa Pirat tried by

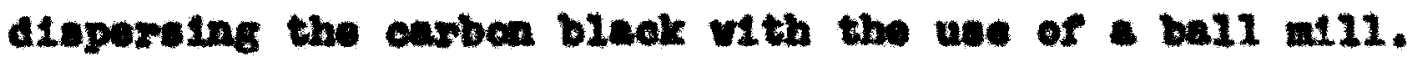
It un not poosible to afrot this dimporaton to atia-

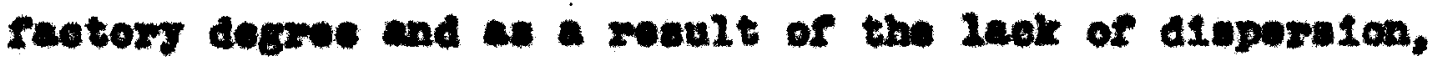
the glone of the fintabod 11 we connidembig roduood.

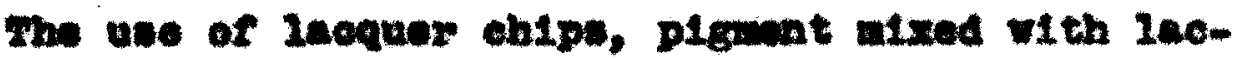

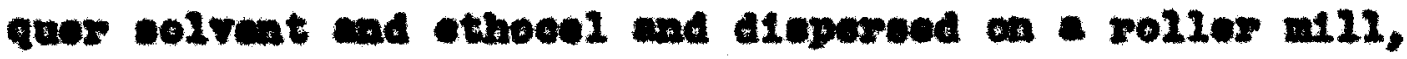

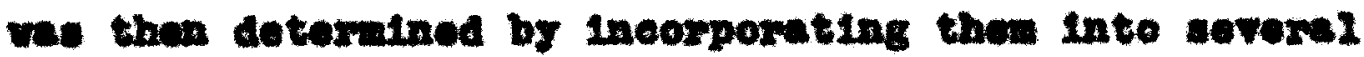


formulations. This wothod of plgwentetion ves not successfuI because there was at111 a leck of glose. It is safe to assum that the Ieoquer chipe vere not vell dieperesed. The problew of diaporation vac finally solvod by using a com-

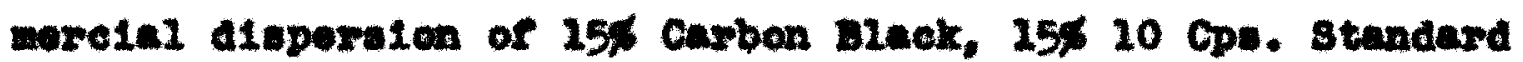
Ethooel, 14\% Ethanol and 56\% Toluol, manufectured by R. B. E. Co, of Bovark, $\mathrm{H}$. $J$. and roferred to as R,B.F. Diaperalon II0. 9002 ,

wany comerciel resins and plattielzer combinetions vere used, such as auperbeckselte 3000 , Dures 570 , Dures 550, Beckedte 1211, Aroples 930, Tricrearl phoophete. onstor 011, d1-oetyl phthalete, oto. The reain and plentic1ser modified elkyd reath ER-1071 manufectured by the Re-

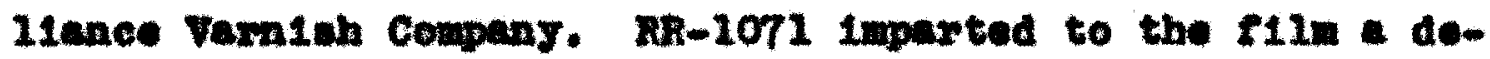
cirable haxdness, adheaton and flexiblilty.

Ithocel, 20 ops, standard thoxy content, ves the only Ethoeel that gave a good hard f1Im. Standard Ethocel and wedium ethocel with viecosities ranging from 7 ops to 50 eps were investigated but no setiafectory resul te wore obtained. 
Tho same diffioulty was oncountered in the Ine-

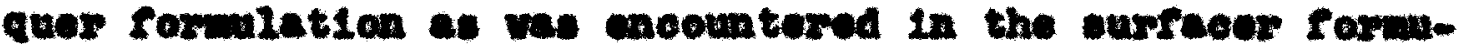
Iation wth reopot to the velvent wet1o. The tim required for the InItial set of the PIIn Introduced the volvent prob10m. If the tim required for the initiel sot wa too thort

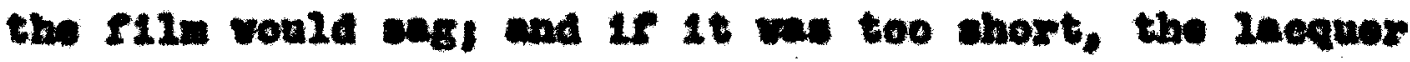
vould hit the panel ary and produce a vory gralny orangepoel wurrace. The solvatis have to be so regulated by the

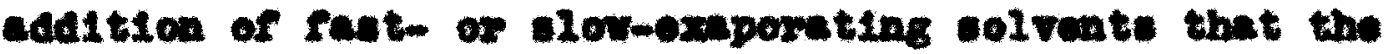

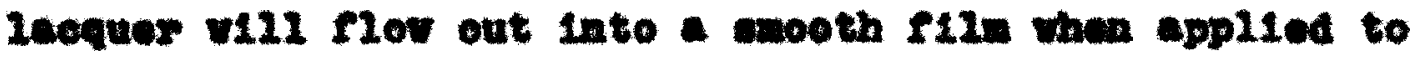
the ourrace to be Iecquoned.

Cold-rolled etoel penele woro ueod to olmalete the bedy of en eutomoblis. Funes panels wore propared by enadine vith no. O sandpapor in the presence of a lecquer colvent in ordor to completely dogrones the eurfeos.

One cout of ourfocer we oprayed on the panel and we allowed to age for twenty-rour howrs at which tim it vas vator sandod with lo. O andipapor to give a porrootly smooth ourfece. One oont of Inoquor we thon applied and

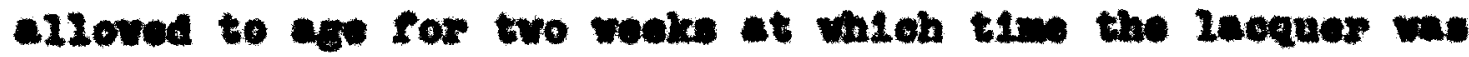


put into an oven at $70^{\circ} \mathrm{C}$ for one hour in order to comploteIf effeot 1 ta curing.

The panels were aubaltted to the "Bend Test" for Plexibility, bardnose toats, and knife-blade toets,

The band tost consteted of bending the panol through $280^{\circ}$ over a $3 / 8$ inch oteel madrel and noting the conditions of the rilm.

The penell bardnese test consisted of seretehing

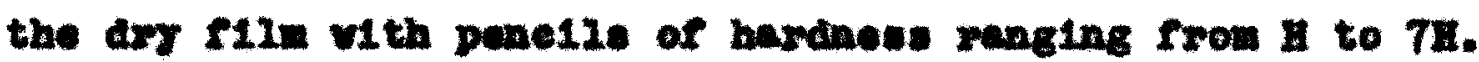
The barder the pencll required to serateh the film, the harder the r11m, e.8., a F12m that required a 58 poned1 to seratoh it vas barder than a f1Im that required a $2 \pi$ pane1I to soxateh 1t. The baxdnoss of the penell sexetohing the surfece designated the buranese of the f12m. The angle of the penoll vith the panel was $45^{\circ}$ and the prescure on the ponc12 wes that usualij used in witing.

The knifo-blede schosion tout vas performod by

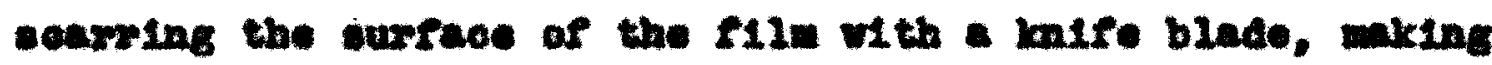
- number of 1 m equares. The reletive ease vith wioh the equares vare romoved wes the Index of adhosica. 
SURPACER FORWULATIO NO. 62

rable I

L1 thopone

Chine cley

cellte crisio

Asboutine

Carbon Black

Ethoce 1

Ethanol

Toluel

Buper neaked te 3000

Aropian 930

Ethanol

roluol

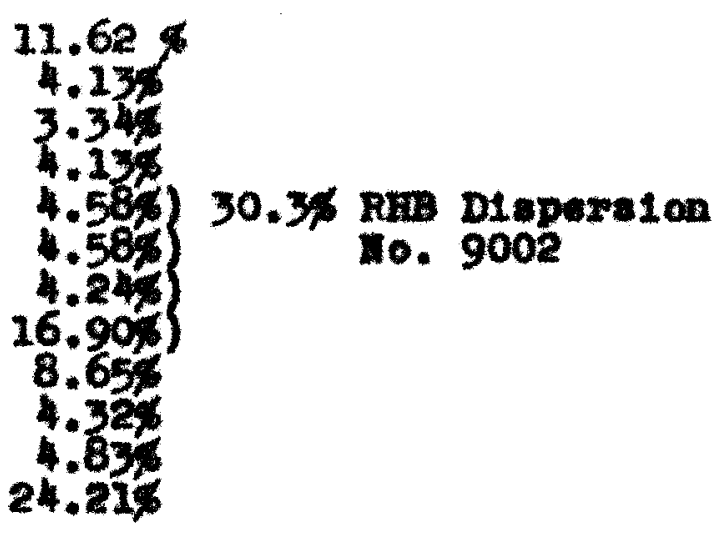

Pragats जILL ORIND

10 eps. Ethoeel ste. ethoxy 4.478

$100.00 \%$

TOP COA FORnouaton no, 62

Carbon Black

10 eps. Ethocel etd. Ethanol

roluol

$10 \mathrm{cps}$. std. Ethoes Aropias 930

super Backec1 to 3000 Ethnaol

Toluol

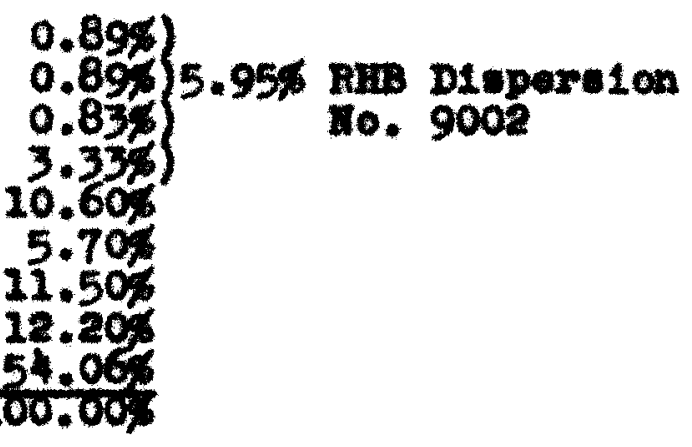


SURPACAR FORMULATrOR NO. 179

\section{Table II}

So11d

50 grams

30 grans

107 grams

83 reams

309 grams
Itanox $B$

Burytes

Soaps tone

(RR-1071 Resin

(50\% xy101:

Toluol

Ethenol

Buteno1

50 ops. Ethoeel std.
Bateh

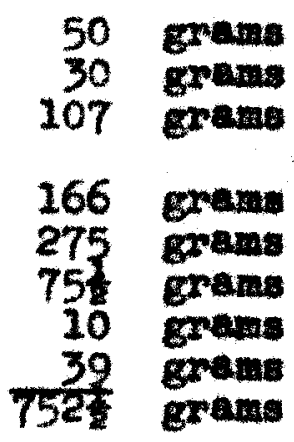

Disperse forty-eight hours in a steel ball mill. Reduce $\left\{\begin{array}{l}1 \text { part } 179 \\ 1 \text { pert } \\ \text { Dow solvent } \# 6\end{array}\right.$ 


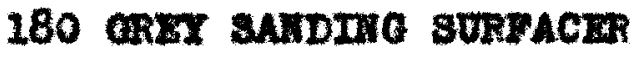

rable II (continued)

This has the same formulation as 179 with the

exception thet 10 ops. standard Ethoes vas used Insteed of 50 ops. Standard Ethoce1.

\section{sungace ronuouarion 10,180 A}

Sol10

$$
\begin{array}{r}
50 \text { gxams } \\
30 \\
107 \text { grams } \\
54.4 \text { gxame } \\
27.4 \text { gxams }
\end{array}
$$

39 grame 307.8 gxams
$T 1 \tan 0 x B$

Barytes

Boeputone

super Beckect to 3000 Aroplaz 930

Toluol

Ethanel

Buthmol

10 epa. Ethocel,

sta.
Betch

50 grams

30 grant

107 Brase

54.4 gxams

27.7 grems

275 grama

78 gram:

10 eram:

38 grams

670.1 grams

D1speres foxty-elght hours in ateel bell w112. Reduce $\left\{\begin{array}{l}2 \text { part } 179 \\ 1 \text { pert Dow Solvent \#6 }\end{array}\right.$ 
SURPACHR PORWULATION HO. $260 \mathrm{~B}$

Table II (continued)

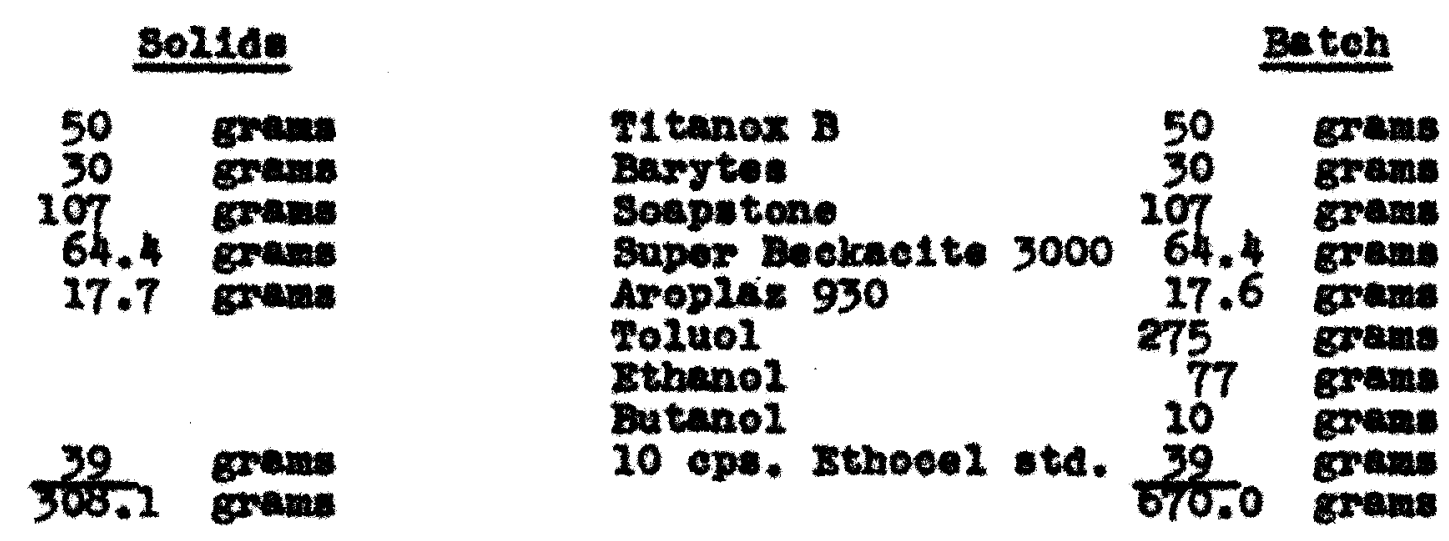

Diaperse forty-e1ght houra in a steel bell mill. Reduce $\left\{\begin{array}{l}1 \\ 1 \\ \text { part }\end{array} 179\right.$ Dow solvent $\# 6$

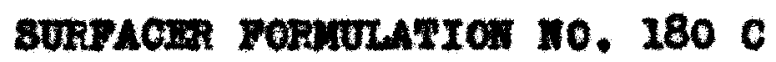

So21de

$\begin{aligned} 50 & \text { grems } \\ 30 & \text { grame } \\ 207 & \text { grams } \\ 7.4 & \text { gram } \\ 7.7 & \text { grams }\end{aligned}$

308.1 grang

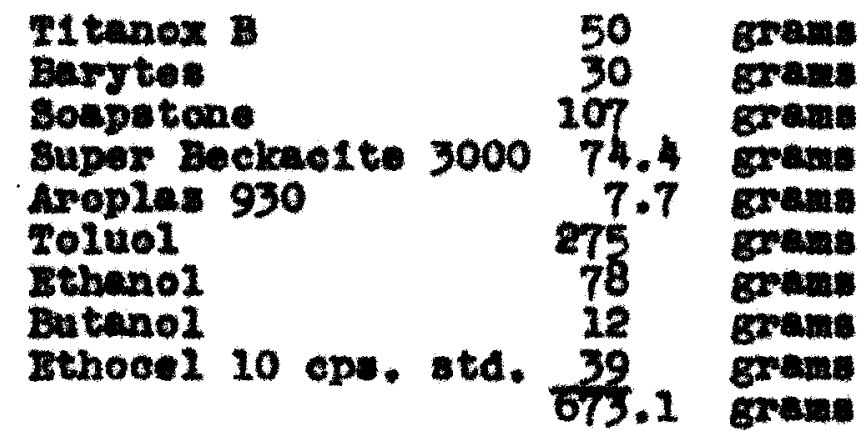

Itenex

Barytes

Soupstone

Supar Deckect to 3000 Aroples 930

Tolvel

Ethano1

Betanol

6r5.1 grand

Dioperse forty-elght hours in ateel ball w11. Reduce $\left\{\begin{array}{l}1 \\ 1 \\ 1 \\ \text { part }\end{array}\right.$ Dow solvent $\# 6$ 
SURPACER FORLULATION IO. $180 \mathrm{D}$

Table II (continued)

So11d

$\begin{array}{rr}50 & \text { gram } \\ 30 & \text { graws } \\ 107 & \text { grams } \\ 72 & \text { grama } \\ 12 & \text { grana }\end{array}$

39 grams 310.0 grams
Atenox $B$

Barytes

Sospstone

Dures 570

Aroplaz 930

Toluol

Ethanol

Buthanol

Ethoeel 10 cps. sta.
Betch

50 exams

30 Grans

107 gram

72 grams

12 grams

2752 gans

erans

Erams

$\frac{39}{675.0}$ grama

$\frac{39}{675.0}$ grama

D1speree forty-1ght hours in a steel ball will.

Reduoe $\left\{\begin{array}{l}1 \text { pert } 179 \\ 2 \text { part Dow solvent } \$ 6\end{array}\right.$

SURPAOER PORUULATION NO. $180 \mathrm{~K}$

Solid

50 grame

$30 \quad$ grams

107 grama

72 grams

12 gxans

$32 \quad$ grams

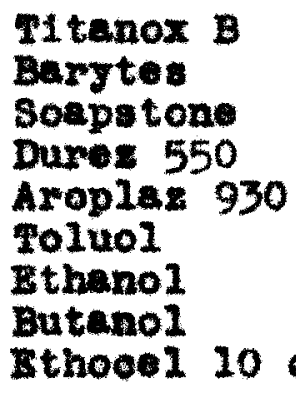

Batch 
TABLE III

TOP COAT FORMULATIONS

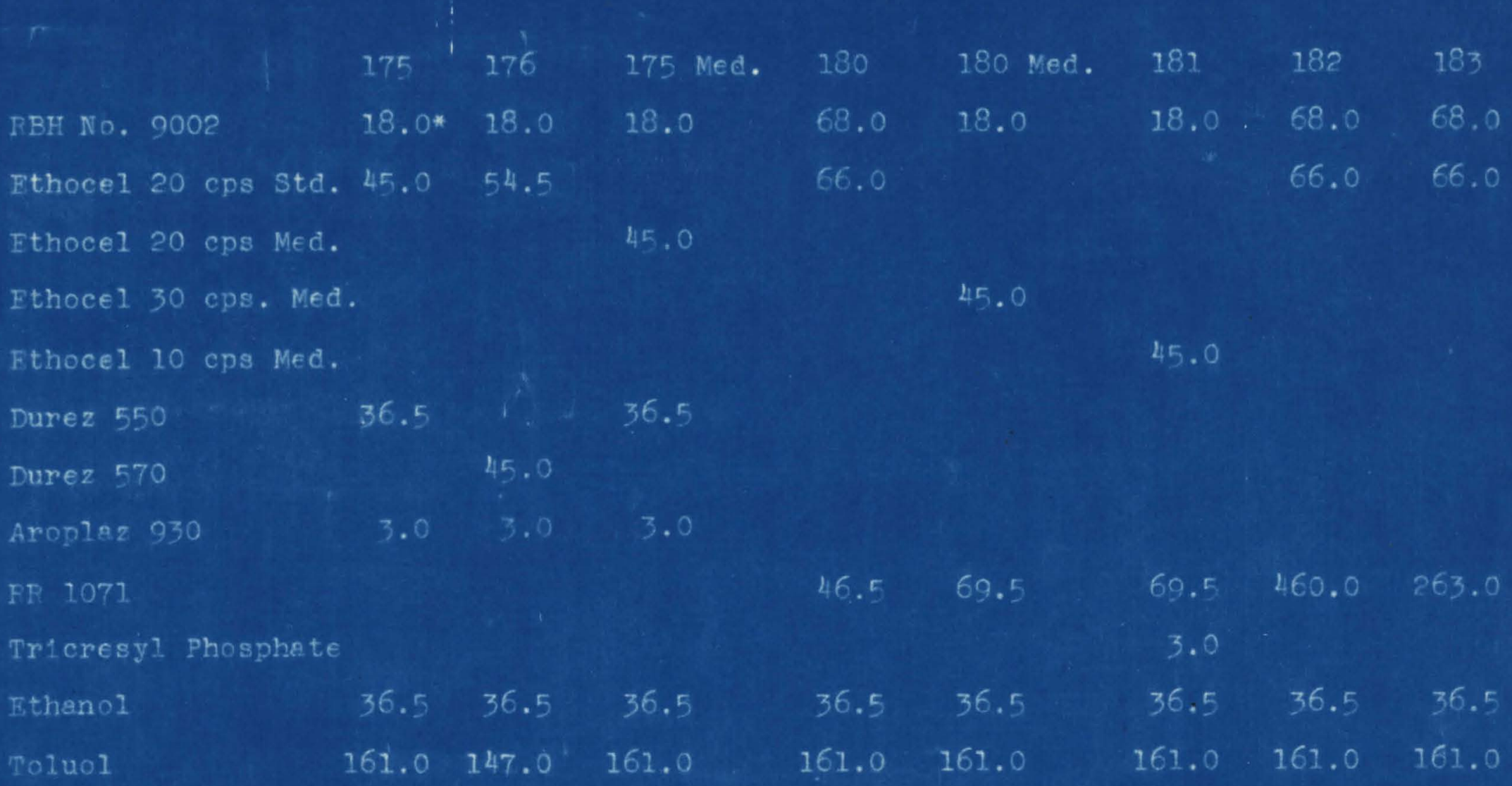

* All weights in grams.

or 
TABLE IV

RESULTS OF TESTS

SURFACER

Pencil Hardness

Adhesion

Flexib111ty
62

$3 \mathrm{H}$

Good
180

$4 \mathrm{H}$
$180 \mathrm{~A}$
211
$180 B$

$3 \mathrm{H}$

Fair

Fair
$4 \mathrm{H}$
1800

$180 \mathrm{D}$

tH

Fair

Fain

Poor

62

$3 \mathrm{H}$

Good

Good

Poor
175 Med. $176 \quad 180$

$2 \mathrm{H}$
180 Med. 181

$4 \mathrm{H}$

Fair

Fair

Good
Fair

Coed
$180 \mathrm{E}$

$3 \mathrm{H}$

Fair

FaIr

182

3H

Good

Good

Good
181

$4 \mathrm{H}$

Good

Fair

close

os

1 
concuusrons 
The grey anading ourfecer showe great posalbility 10 the connerolal field beoune it exhiblte proportles that are sceond to no ourfacos on the naket today. surfecer Ho. 179 is the formulation that is zeoomnonded mowe a surfecer of good harthose, floxtbility and athesion 10 roquired. Ithoeel used in an automobl2. 1neques will not reagh the mrket with the present resins thet are aveliable, and in the ruture, no further rork should be cone of this

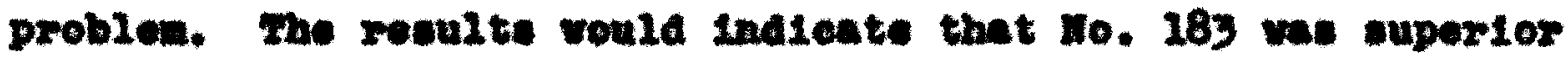
to all the other laoquere investigated, but won the riln was two nenthe old the oll uned to wodsfy reatn MR-1071 vas complotely oxidised and the filn loet oll of 1 to plex18121ty.

The Dow Ohouteal Company of Mlarand, Mtohigan, for thon this resesroh we ocncueted cencure on the cbove conolunions.

It Is rooommadod that this roseareh conelude the problem of doveloping on othoeel touch-up lecquor beanuse of the nogative rooults obtained in this and in othor inveotigations. 
24ne $\mathbf{2}$

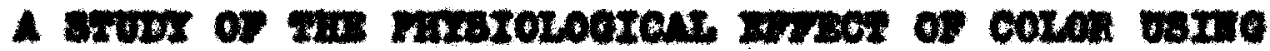

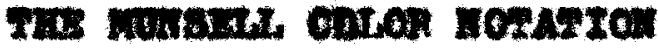




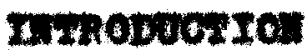


The purpose of this resenreh was to determine the ohange in ahade proforred by a oustomar if his favorite color vore to ohange due to age. This change 1 s one thet has bean notleod an proteotlve conting ages and ohanges from one chede of a color to an ext1rely affrerent enade. rnoving the proference of the custowar, thts obange my be wade pleantag of displeasing dopanding upen the formalation of the besto eelor. This atudy ut111sed the nuneell Color Notation (13) that 1s deseribed in the rollowing pages. 
HIsxon Icat 


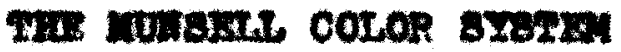

the desoripticn and elassifieation or colors vore bejond the ocope of any language unt1l M. Mibert $H$. Hunsell ut11ised the akeloten 1does of his predecessors in orfetinsting the oolor syetera nov bearing his nawe.

Cherreul, a pleneer in the rield of color study, pexformed some very uplendid work on a color oyeten, but it was of rory little velue to the Iagrean becanse it vas based on the Irrogulartties of vartous are and plgant alxtures. The lint tations and the complications of ouch a oyeten are obvious. The ropreduction of certain colors by uning the seme proportions of Identien plemate of difrerent betehos vouzd rory qutekis olip into the realn of the Imposelble. Dolmolts, a great weintiet of his day, who gave conoldermbie attention to the Insdequedes of Chorroul': oreten, etated that color bea three dinemo10ne. Wle theory

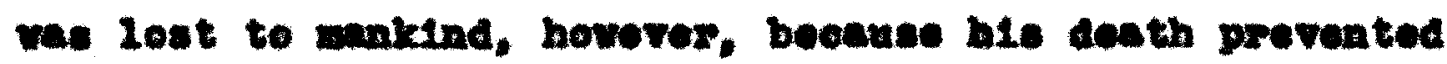
1te prosentation.

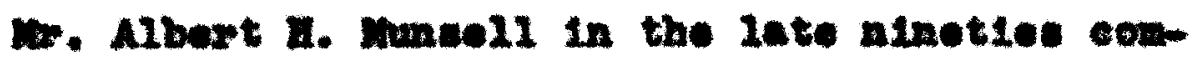
bined his ldeas with those set forth by Chorroul and Eolm- 


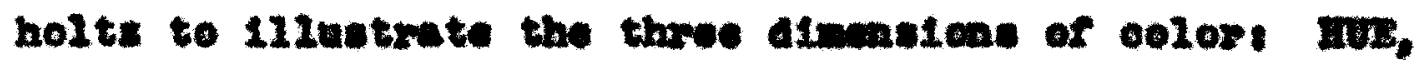
varue and cinoun.

IU: That proporty of color whioh exlowe you to dietinguteh botwoen red and greed, green and yellor, blue and purple, and all other difforent baslo oolore. Ine 10 desigated by the following lettores I for red, In for yel20v-med, I for je120r, ete. We is the firat obarector1otie of colos that the ore can dotect.

Varos: Detween the two extromes of a pure wite, wo light that no color wy be seos in 1t, and a pure black, wo enze that no color can be wom in 1t, way be detingutebod varlous dogreos of 11 ght etrongth that v111 range rrom

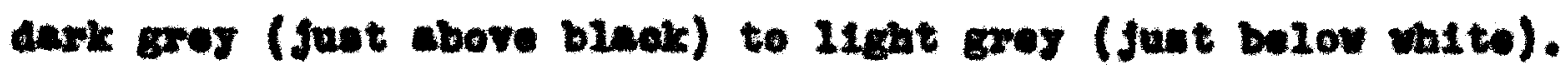
For example, yellow is uevally a light color nearer to white then to bleck! purple-blue is usuilis a dark color nearer to black than to whte. IhIs rariable 11 ght otrength

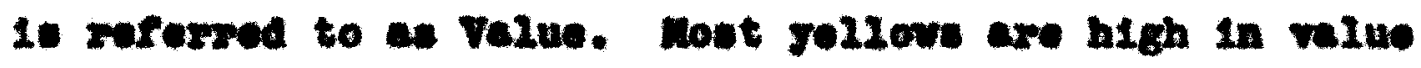
and noet purple-blues are 201 in value, but elthor on be Juat the opposite.

Fure wite and pure bleak are at the prosent time unobtainable. Pure bleck is desienated by the numorieal 
value of 0 and pure mite 1s destennted as 10 . The blacks that are readily produceable eoldon fall beloy the numertcel value of 1 and hites seloom go higher then 9. Practiceliy, pure black 1s obtainable by lining a box wth black velvet and looking into it through a hole in the cover. Pure menentun oxide epproaches pure white by a value of 9.7 to 9.9 .

It 1s noted that 5 is the alddle value between pure white and pure black. Pure greg la found on the neutrel axis and 1s designeted as $\mathrm{x}^{4}, \mathrm{w}^{5}, \mathrm{x}^{8}$, ete., depending upon the velue posseseed by the perticuler grey.

If any color is oompered with the different greys of the ceele, it is easy to alstingulah the value of the partieular color. The value simply indieates hov $11 \mathrm{ght}$ or how dark a color 1s, $R^{5}, T^{5}, f^{5}$, and $P^{5}$ are all the same value, so one is nelthor lightor nor derker then tho other. (Bee Fig. I for a graphic 11lustration of Velue.) CrRous: Two colore ma have the same hue and also the sawe relue, but one 10 a stronger color than the other. Th1s property of color is called ohrom. Chrom measures 
the degree of strength the color possesses.

Chrom is measured on ithe pexpendieular to the value axis from $/ 0$ at the axis out to $/ 10$ representing the trongest Chrome obtainable for the part1cular hue. For example, a ereen mldvay between black and m1te, flve stopo out, in chrom is represented by $65 /$. 


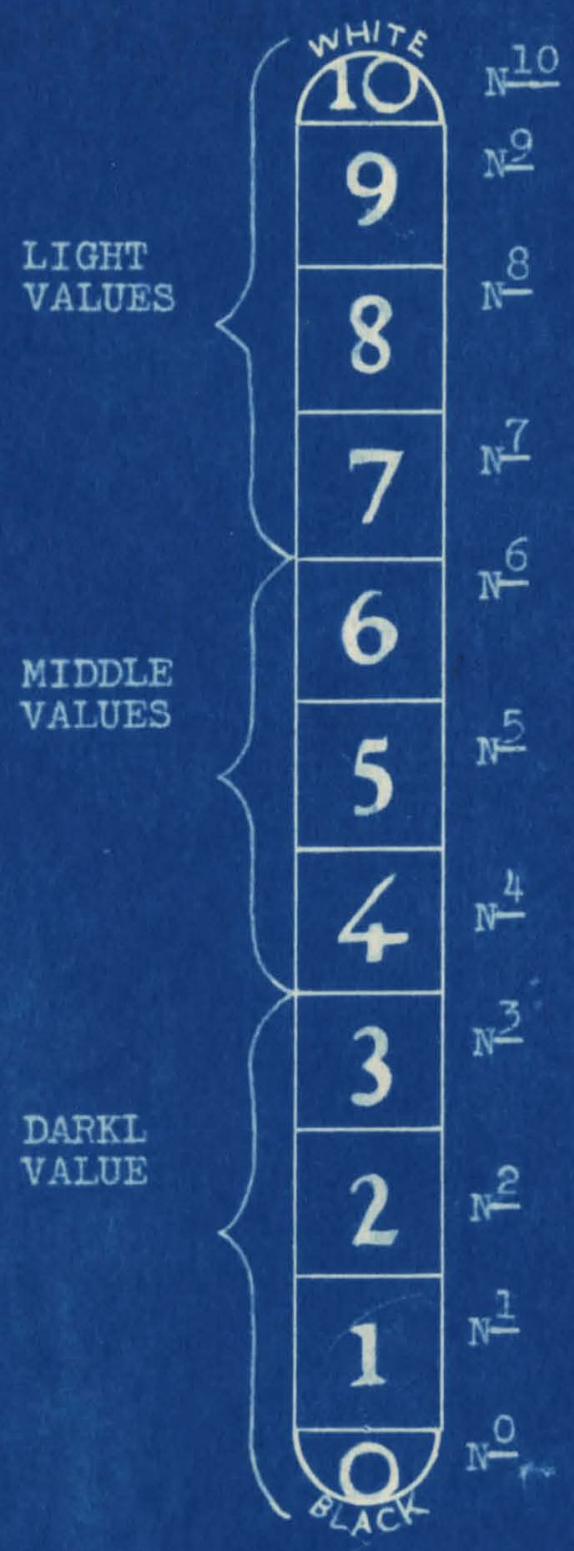

FIGURE I

SCALE OF MUNSELL VALUES ON THE NEUTRAL AXIS 


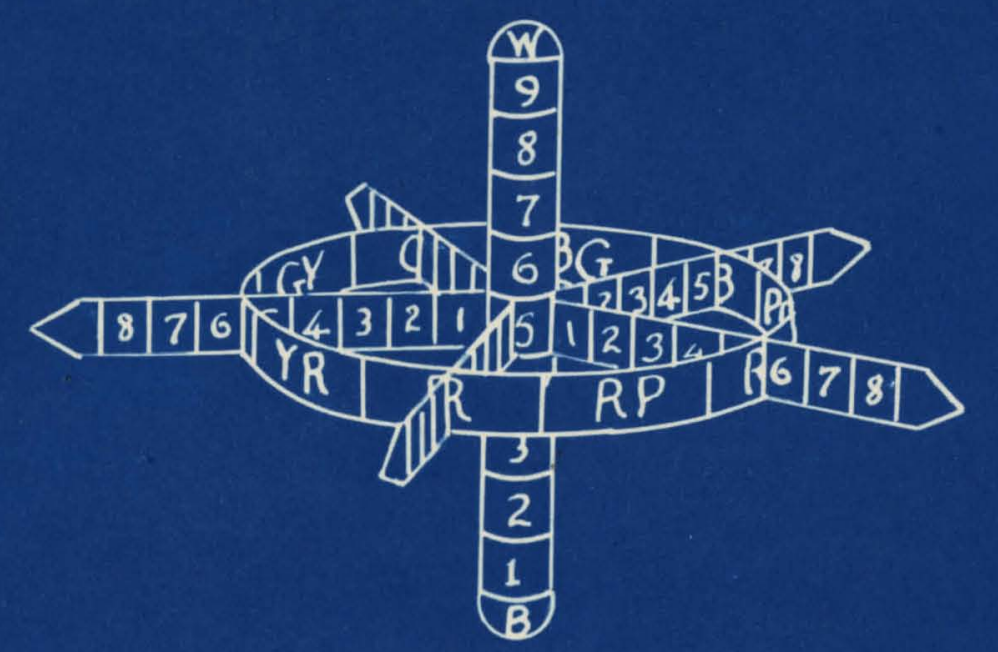

Iue, Value and Chroma Dlagram

(Their Relationships to Each Other)

A hue reaches its maximum chroma at only one value, and all hues do not reach their maximum chroma at the same level of value. The following hues wero invest1gated as a partial fulfiliment of this study: red, jellow and red-green. 
TEST PROCEDUR 
The Hunsell color chips vere erranged as thoun in rebles IV, $v$ and $v I$ on the "Individual Analsals sheet shovIng the Munsell color card Arrangement." the center chips of Board II on the above cherts vere the standarde in each color sot. This tandard oolor vas show to the observer and the observer was asked to aseume that this color vas one thet he vould like to have but that he could not obtein. Folloving this aseumption, the observer ves given a cholce of the corresponaing oolor on Board I or III, that is 2.5 $6 / 6$ and $7.5-6 / 6$. This deternined the observer's hue preference.

Second, frow the board containing the observer's hue preference, the observer was again asked to choose between two colors representing a ifrerence in value, but of the some he and ohrom as the firat selection. Bxamples Green $506 / 4$ vas the green atenderd. The observer chose between $2.506 / 4$ and $7.506 / 4$. suppose the observer had chosen $2.566 / 4$. Then, his next cholce was between $2.507 / 4$ 
and $2.505 / 4$.

Third, the observer chose color of the same hue and value as his second cholee, but of different chroman. Fourth, the observer vas alloved another cholce in value. Suppose thet in the example cbove, the observer's cholce we $2.507 / 4$. Ho was then given a cho1ce between $2.507 / 6$ and $2.507 / 2$. If he then ohose $2.507 / 2$, he ves given aholee between $2.507 / 2$ and $2.506 / 2$, alloving him to reverse a former tendeney.

Hany observers Ald reverse themelves in the fourth cholce, and when these observers vere questioned, it was alselosed that the original choles in value ves too extrene to oult thom. Mis moans that in the exauple, the observer did not $11 \mathrm{ke} 2.505 / 4$ or $2.507 / 4$, but that 2.50 $7 / 4$ was the wore plenelng color and wore in the range thet be vould sccept. Plnal selection of $2.506 / 2$ moant that he 11ked the neutrel velue better then $2.507 / 2$.

A firth chotee vas allowed on the rad and part of the Jellou-reds and greens. This cholee vas mode in a hue between the firet hue chosen and the etandard bue. In the 
example above, if the obeerver' fourth obo10e hed been $2.506 / 2$, then he voule bere been allowed to choose between $2.506 / 2$ and $5.06 / 2$. Selection of $506 / 2$ vould indleate that the 2.5 hue vas more ecceptable then the 7.5 hue, but that 2.50 vas too extrewe or that the noutrel 50 vas more desiruble.

All colors vere covered during the toot except those which vere being hown to the observer. In the firet cholee, eards $2.506 / 4,506 / 4,7.506 / 4$ were open for the eelection of elther $2.506 / 4$ or $7.506 / 4$. Then, these colore vere covered, and $7 / 4$ and $5 / 4$ vere uncovered on the boerd of riret selection, etc. The obeervere vere inetrueted to choose on the werlt of the color rether than to try to match vith the standard. Observers wore also instructed to refrain from choosing the color merely becanse it vould look pretty on some pertieular objoct. 
TABLE I

INDIVIDUAL ANALYSIS SHEET SHOWING MUNSELL YELLOW-RED CHIP ARRANGEMENT

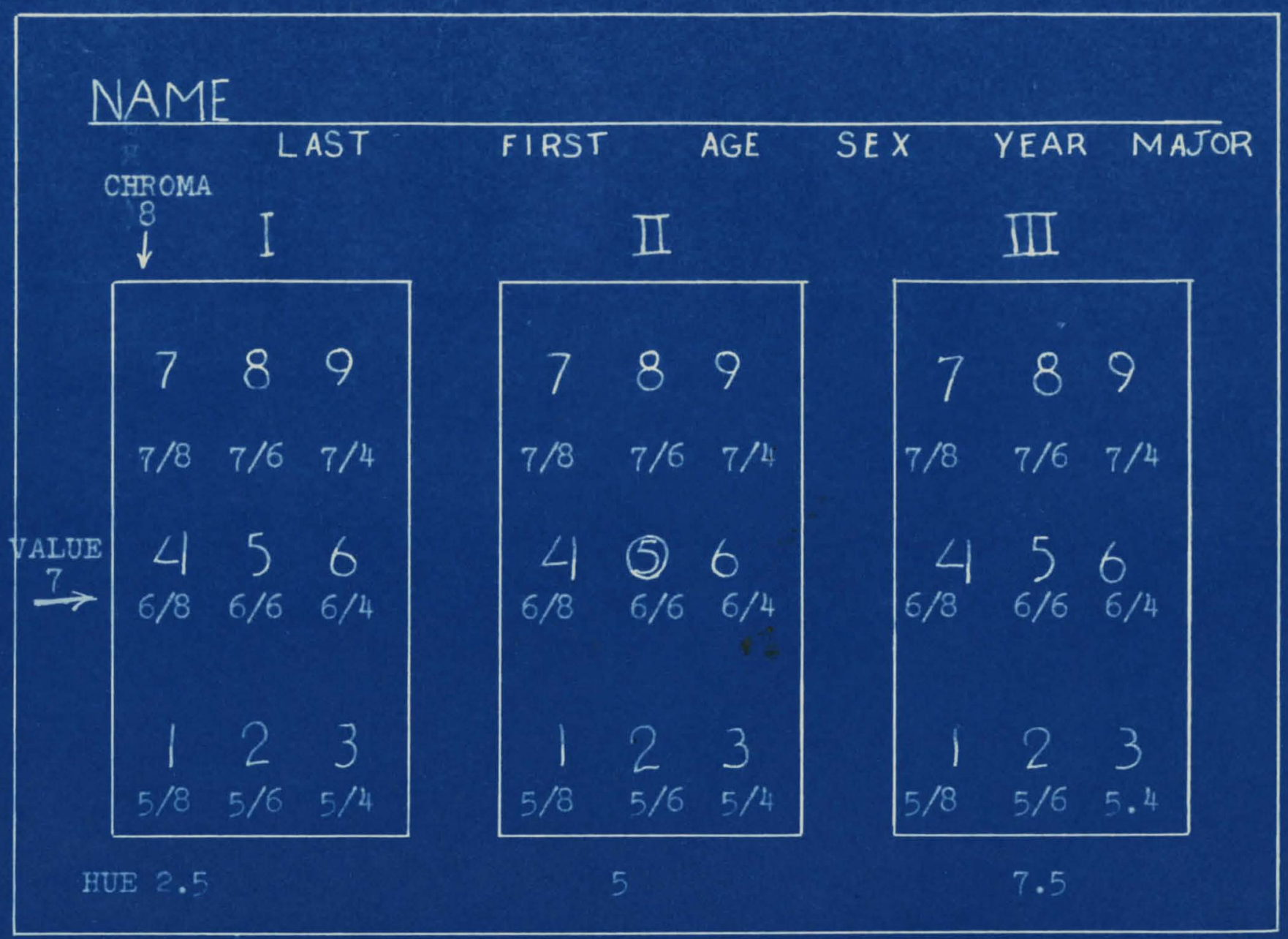


TABLE II

INDIVIDUAL ANALYSIS SHBWT SHOWING MUNSELL RED CHIP ARRANGEMENT

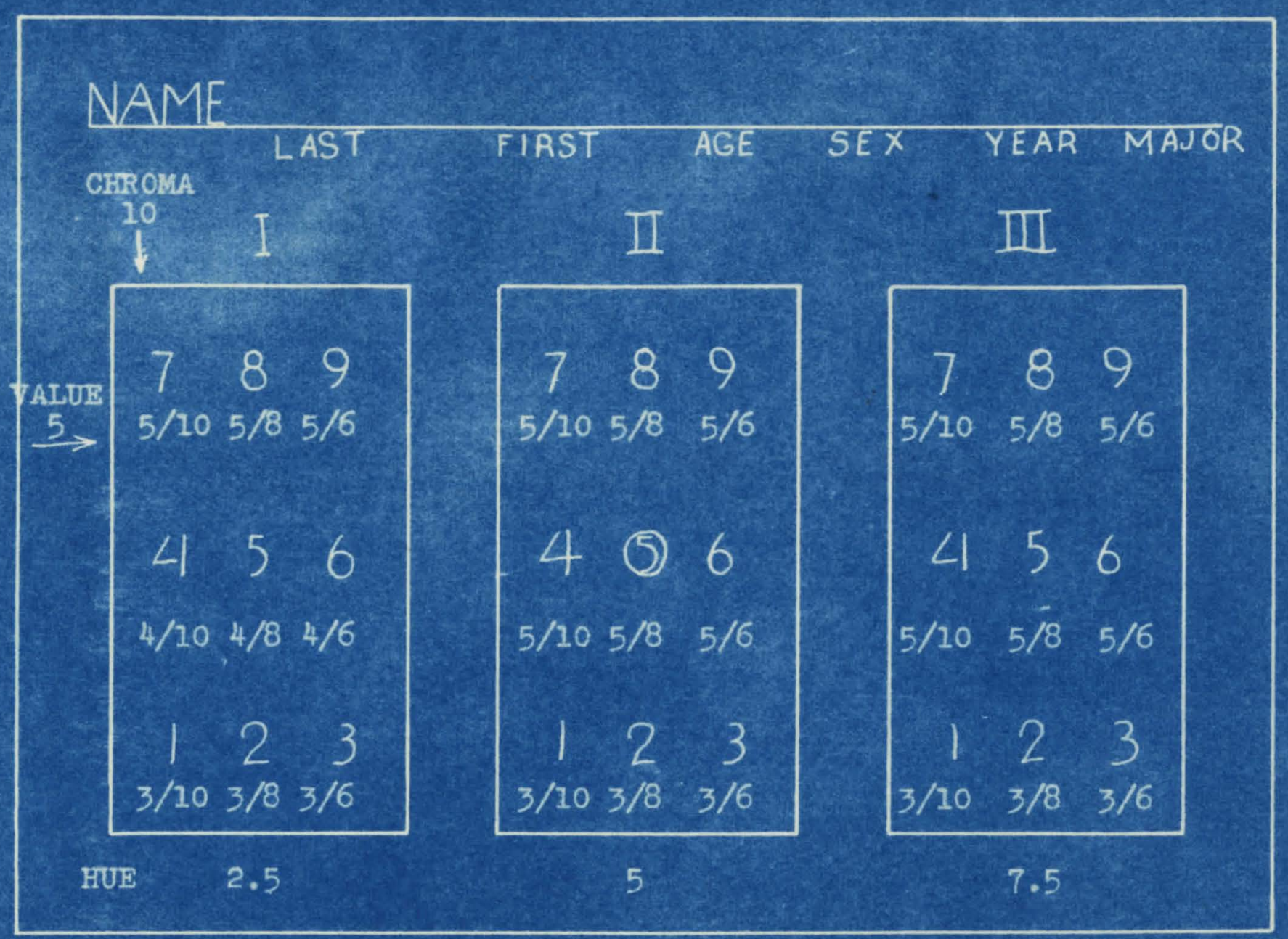


Thde was

INDIVIDUAL ANALYSIS SHEMT SHOWING MUNSELL GREEN CHIP ARRANGEMENT

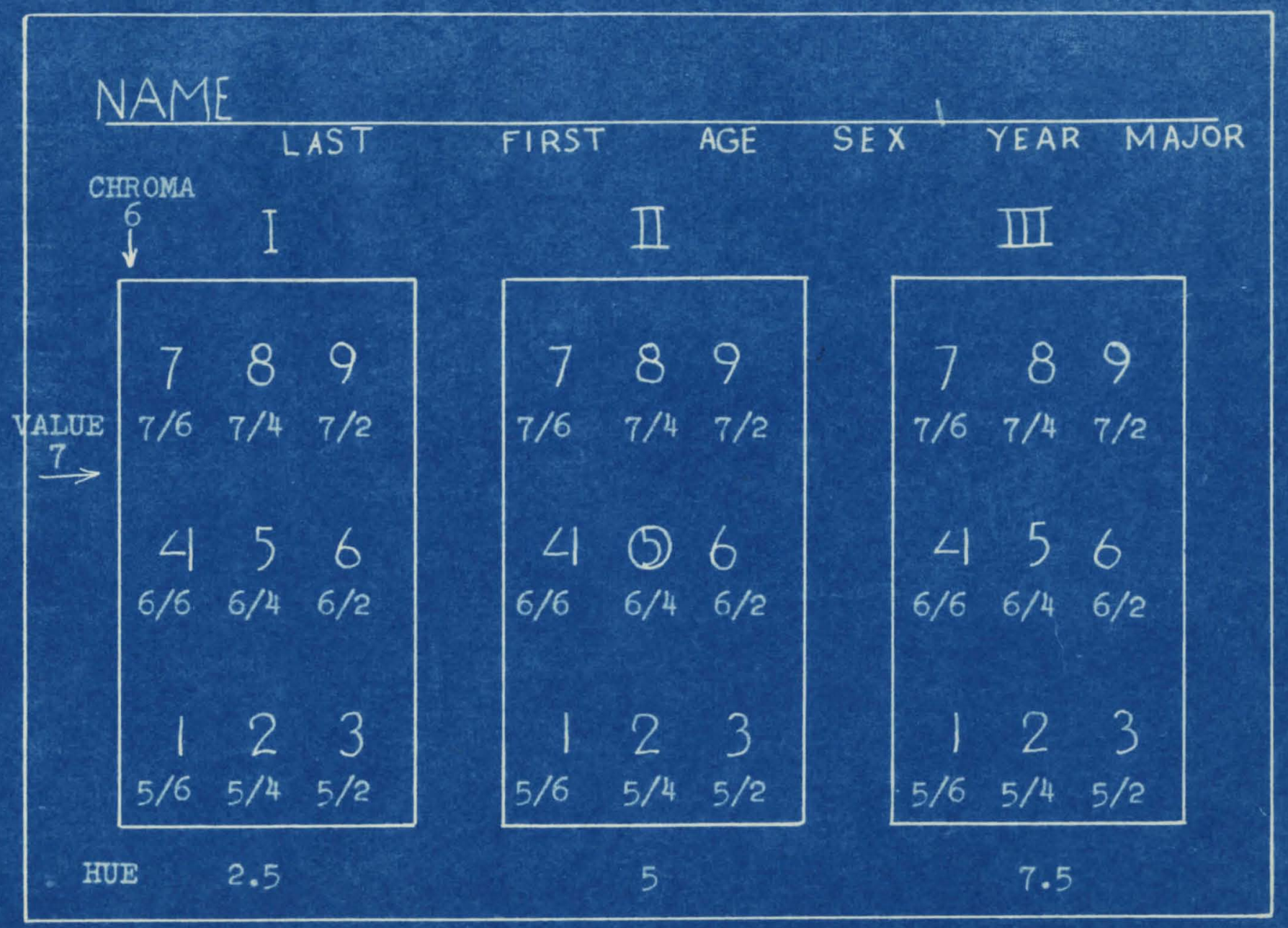


TABLE IV

CONVERTING HUNTER REPLECTOMETER VALUES TO THE BUREAU OF STANDARDS COLOR VALUES STANDARD 2.5 GREBN

\begin{tabular}{|c|c|c|c|c|c|c|c|c|c|}
\hline & $6 / 4$ & $5 / 2$ & $6 / 2$ & $7 / 2$ & $5 / 4$ & $7 / 4$ & $5 / 6$ & $6 / 6$ & $7 / 6$ \\
\hline 81ue Settings (Hunter) & .253 & .184 & .272 & .373 & .158 & .344 & .144 & .212 & .318 \\
\hline Amber Settings (Hunter) & .262 & .188 & .280 & .384 & .171 & .362 & .158 & .230 & .348 \\
\hline Green Settings (Hunter) & .313 & .211 & .320 & .414 & .210 & .423 & .208 & .301 & .433 \\
\hline$B=.803 \times$ Blue & .2035 & .148 & .219 & .300 & .127 & .2765 & .1158 & .1705 & .256 \\
\hline$A=.816 \times$ Amber & .214 & $.153 \dot{5}$ & .2285 & .313 & .1395 & .296 & .129 & .1875 & .284 \\
\hline$Y=d^{\prime \prime}=.817 \times$ Green & .255 & .172 & .253 & .338 & .1715 & .345 & .170 & .2455 & .354 \\
\hline$L=Y 1 / 2=G 1 / 2$ & .505 & .415 & .504 & .583 & .416 & .588 & .411 & .496 & .596 \\
\hline $\mathrm{L}=\mathrm{K}_{1} \quad\left(\mathrm{Y}_{1 / 2}\right)$ & : & -9.0 & -.1 & +7.8 & -8.9 & +8.3 & -9.4 & -1.9 & +9.1 \\
\hline A-C (Note S1en) & -.041 & -.0185 & -.0245 & -.0250 & -.0320 & -.050 & -.041 & -.0580 & -.070 \\
\hline $\mathrm{C}-\mathrm{B}$ (Note S1gn) & +.0545 & +.024 & +.034 & +.038 & +.0445 & +.0685 & +.0542 & +.0750 & +.098 \\
\hline $.4(G-B)$ & .0218 & .0096 & .0136 & .0152 & .01785 & .0274 & .02165 & .030 & .0392 \\
\hline Dem. $=B+A+2 G$ & .9275 & .6455 & .953 & 1.289 & .6095 & 1.2615 & .5848 & .8490 & 1.248 \\
\hline$\alpha=A-G / D \in m$ & -.04425 & .02865 & .0257 & .0194 & .0525 & .0396 & .070 & .0683 & .0561 \\
\hline$\beta=.4(G-B)$ Dem. & +.0235 & .01487 & .01297 & .0118 & .0292 & .0217 & .037 & .0353 & .0314 \\
\hline$\sqrt{\alpha^{2}+\beta^{2}}$ & .0501 & .0323 & .0288 & $: 0227$ & .0600 & .0452 & .0792 & .0770 & .0650 \\
\hline$\Delta\left(\sqrt{\alpha^{2}+\beta^{2}}\right)$ & & -.0178 & -.0213 & -.0274 & +.0099 & -.0049 & +.0291 & +.0269 & +.0149 \\
\hline $700 \times 1 / 4$ & $.7 \frac{11}{498}$ & $\begin{array}{r}644 \\
451\end{array}$ & .709 & $\begin{array}{r}.763 \\
534\end{array}$ & $\begin{array}{r}.644 \\
451\end{array}$ & $\begin{array}{r}.767 \\
537\end{array}$ & $\begin{array}{r}.642 \\
450\end{array}$ & $\begin{array}{r}704 \\
493\end{array}$ & $\begin{array}{r}772 \\
540\end{array}$ \\
\hline$\Delta s=700 \times 1 / 4 \Delta \sqrt{\alpha+\beta}$ & & -8.03 & -10.6 & -14.5 & +4.46 & -2.63 & +13.1 & +13.1 & +8.05 \\
\hline 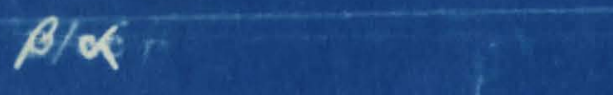 & .532 & 519 & .504 & .607 & .557 & .548 & .529 & & .56 \\
\hline $\begin{array}{l}\phi=\text { Angle whose tangent } \\
\text { is } \beta / \alpha\end{array}$ & $\begin{array}{l}28 \\
152\end{array}$ & $\frac{27.4}{152.6}$ & $\begin{array}{l}26.75 \\
153.25\end{array}$ & $\begin{array}{l}31.25 \\
148.75\end{array}$ & $\begin{array}{l}29.8 \\
.150 .2\end{array}$ & $\begin{array}{l}28.7 \\
151.3\end{array}$ & $\begin{array}{l}27.88 \\
152.12\end{array}$ & $\begin{array}{l}27.28 \\
152.72\end{array}$ & $\begin{array}{l}29.25 \\
150.75\end{array}$ \\
\hline$\Delta \phi$ & & +.6 & +1.25 & -3.25 & -1.8 & -.7 & +.12 & +.72 & -1.25 \\
\hline $12.2 \times 1 / 4$ & 8.67 & 7.87 & 8.66 & 9.32 & 7.87 & 9.33 & 7.83 & 8.59 & 9.42 \\
\hline $12.2 \times .1 / 4 \sqrt{\left.\alpha^{2}+B^{2}\right)}$ & & +4.72 & +10.82 & $-30 \cdot 3$ & -14.15 & -6.53 & +.94 & +6.18 & -11.77 \\
\hline $\begin{aligned} H= & 12.2 Y 1 / 4 \sqrt{\alpha^{2}+B^{2}} \\
& \Delta \phi\end{aligned}$ & & +.1475 & +.312 & -.687 & -.85 & -.295 & +.0745 & +.476 & -.76 \\
\hline
\end{tabular}




\section{TABLE V}

MEASUREMEITS OF HUE, VALUE AND CHROMA DIFFERINCE ESTIMATES BETWEFN MUNSELL COLOR CHIPS FOR 5 GREEN

\section{STANDARD}

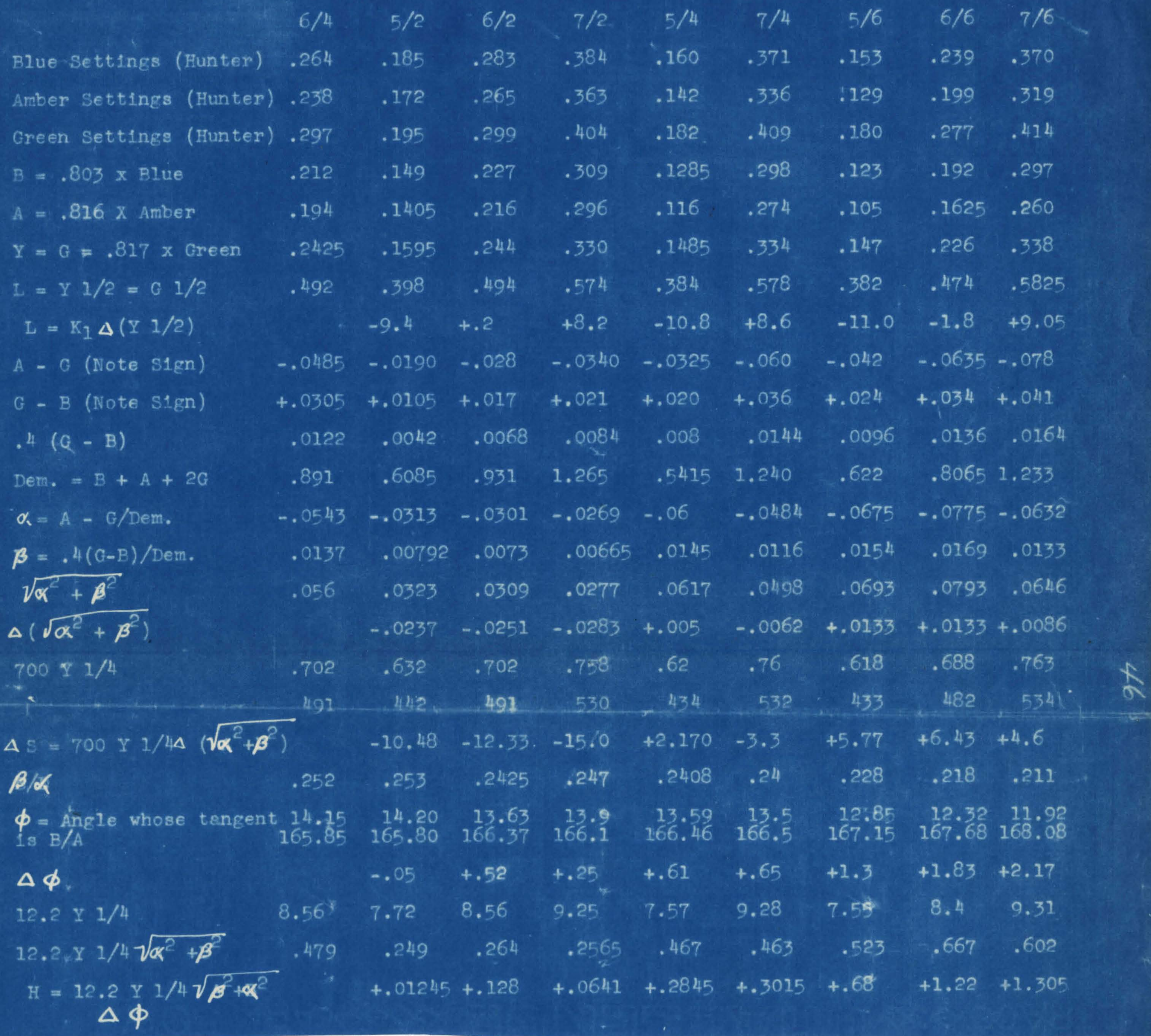


TABLE VI

MEASUREMENTS OF HUE, VALUE AND CHROMA DIFFERENCE ESTIMATES

BETKEEN MUNSELL COLOR CHIPS FOR 7.5 GREEN STANDARD

$6 / 4 \quad 5 / 2 \quad 6 / 2 \quad 7 / 2 \quad 5 / 4 \quad 7 / 4 \quad 5 / 6 \quad 6 / 6 \quad 7 / 6$

Blue Sett1ngs (Hunter) .303

.187

.288

.421

.183

.413

.190

.300

.412

Amber Settings (Hunter) .253

.172

.269

.400

.151

.357

.138

$.235 \quad .342$

Green Sett1ngs (Hunter) .322

.196

$\mathrm{B}=.803 \times$ Blue

.2435

.307

.442

.198

.424

.199

.325

.433

$A=.816 \times$ Amber

.1504

$.2315 \quad .339$

.147

.332

.153

.241

.331

$Y=G=.817 x$ Green

.2065

.1405

.2195

.3265

.123

.291

.1125

.1915

.279

$L=Y 1 / 2=G 1 / 2$

.263

.160

.251

.361

$.1615 \quad .346$

.1625

.265

.354

$\mathrm{L}=\mathrm{K}_{1} \Delta\left(\begin{array}{ll}\mathrm{Y} & 1 / 2)\end{array}\right.$

.513

.39

.502

.591

$.401 \quad .589$

.403

$.514 \quad .595$

$-11.4$

$-01.1+12.2$

$-11.2$

$+07.6$

$-11.0$

$+00.1+08.2$

$A-C$ (Note $\mathrm{Sign}$ )

$-.0565$

$-.0195$

$-.0315 \cdot . .0345$

$-.0385$

$-.055$

$-.050$

$-.0735-.075$

$\mathrm{G}-\mathrm{B}$ (Note $\mathrm{S1gn}$ )

$+.0195$

$+.0096+.0195$

$+.022$

$+.0145$

$+.024$

$+.0095$

$+.024+.023$

$0.4(G-B)$

$+.0078$

$+.00384+.0078$

$+.0088$

$+.0058$

$+.0056$

$+.0038$

$+.0096+.0092$

Dem. $=B+A+2 G$

$$
.9761
$$

.6109

.9531

1. 3675

.5931

1.315

.5905

.96251 .318

$\alpha=A-G / D e m$.

. .0579

. .0319

$-.0330$

$-.0252$

$-.0648$

$-.0418$

$-.0847$

$-.0764-.0569$

$\beta=0.4(C-B) /$ Dem.

$\sqrt{\alpha^{2}+\beta^{2}}$

$+.0080$

$+.00628+$.

.0585

.0310

$+.006425+$.

$.00977+.0$

.00426

$+.00513$

$+.00997+.006975$

$700 \times 1 / 4$

$\begin{array}{ll}-.0260 \quad-.024 & \end{array}$

.026

.0655

.0421

.085

$.077 \quad .0573$$$
\text { . }
$$$$
-.0325+.0070
$$

$-.0164$

$+.0265$

$+.0185-.0012$

.716

.708

$.775 \quad .633$

.767

.635

.717

.772

\section{1}

$442 \quad 496$

542.

443

537

444

$502 \quad 540$

$S=700 \times 1 / 4 \Delta\left(\sqrt{\alpha^{2}+\beta^{2}}\right)$

$-11.5-12.13$

$-17.6$

+3.1 .

$-8.76+11.75$

$+9.3-.648$

$-.1382$

$-.1972-.248$

$-.255$

$-.2508$

$-. .104$

$-.076$

$-.131-.1206$

$\boldsymbol{\phi}=$ Angle whose tangent 7.87

$1 \mathrm{~s} \beta / \alpha$

$\triangle \phi$

12.2 Y $1 / 4$

12.2 Y $1 / 4 \sqrt{\alpha^{2}+\beta^{2}}$

$=12.2$ Y $1 / 4 \sqrt{\alpha^{2}+\beta^{2}}$

$\Delta \phi$ $\begin{array}{llll}11.17 & 13.94 & 14.32 & 8.58\end{array}$

$\begin{array}{llll}168.83 & 166.06 & 165.68 & 171.42\end{array}$

$\begin{array}{ll}-3.30 & -6.07\end{array}$

$\begin{array}{ll}-6.45 & -.71\end{array}$

8.63

9.45

7.72

5.95

4.36

174.05

$+1.92$

$+3.51$

9.35

7.75

.658

$7.47 \quad 6.88$

8. $73-7.7$ .512

.25

.294

$.2455 \quad .505$

.394

$-1.585-.3585$

$-1.785$

$+.757$

$+2.31$

$+.40$

8.74

$-.99$

$-.825$

$-1.785$ 


\section{SArra cancomatous}

The procedure for converting Ilunter Reflectoweter readinge to Bureau of stendards values is covered in the Bureau of Standards C1roular Cheg "Photoeleotric Tr1stimulus Colorimetry vith Three Fiters." (24) The folIoving sample ealouletion mediures the due difference eet1mate, $\mathrm{H}^{2}$, the aturation difrerence estimate $\mathrm{s}^{2}$, and the 11ghtnese difference estuate $\mathrm{L}^{2}$, between an ectual carth sample and two wodified earth. Computationel ahort cuts winus scale correction antted, no celabrated standard used, and factor 0.5 used inetead of the actual transaleato of noutral ri1ter. $k_{1}=200,8=1.00$. 
SPECTMEN

Blue reading

$\mathrm{B}=\mathrm{Above}$ times

0.5

Amber reading

$A=$ ebove times 0.5

EARTH MIXTURE

0.295

.147

.496

.248

Green reading

$Y=G=$ Above $\times 6.5$

$I_{L}=I / 2=6 \frac{1 / 2}{I}-K_{1} \Delta(Y I / 2)$

$A-G$ (Note S1gn)

$G-B$ (Note S1gn)

$0.4(C-B)$

Demoninator $=\mathrm{B}+\mathrm{A}+2 \mathrm{C}$

$A=(A-C) / d e m$.

$\mathrm{B}=0.4(\mathrm{G}-\mathrm{B}) / \mathrm{dem}$.

$\sqrt{a^{2}+a^{2}+B^{2}}$

$700 Y 1 / 4 *$
$\Delta S^{1}=700 \times 1 / 4 \sqrt{L+B^{2}}$

$B / B$

$\Delta$ whose ton $1 \mathrm{~s} B / \varepsilon$

$\Delta \phi$

$\begin{array}{lll}12.2 & \text { Y } 1 / 4 * \\ 12.2 & \text { Y } 1 / 4 & \sqrt{A^{2}+B^{2}}\end{array}$

$\Delta H=12.2$ Y $1 / 4 \sqrt{A^{2}+B^{2}}=\Delta \phi$

color of med, relative to

that of actual earth, eccording

to measurement.

.428

.453

$+.034$

$+.0665$

$+.0266$

.8235

$+.0413$

$+.0323$

.0525

$+.782$

$38.03^{\circ}$
MODIFICATION

\#1.

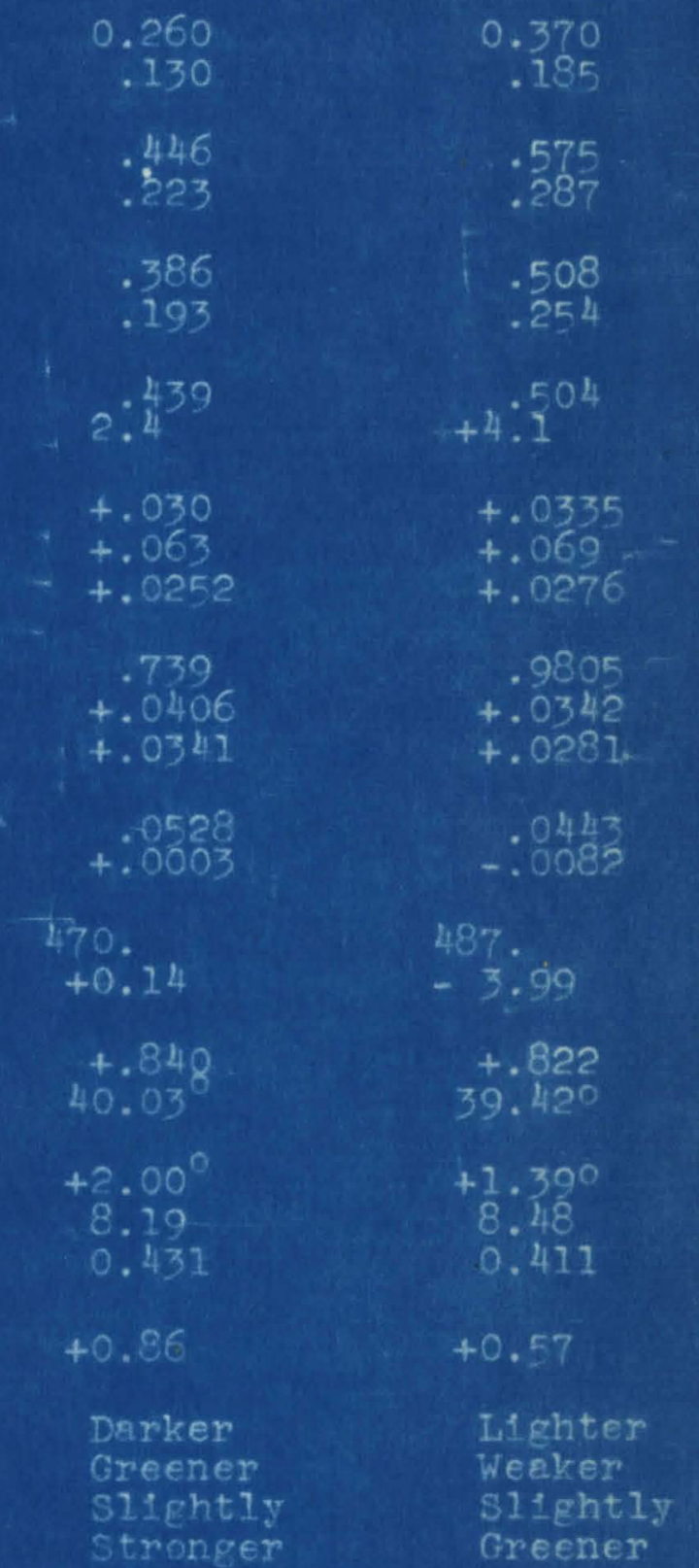
\#2

stronger
MODIFICATION

* Ave. for 2 specimens belng compared should be entered in those rows marked by asterisk. 


\section{IXPLARATIOA OP TABLBS}

Tables VII, VIII and IX 111ustrate the 11kes and the dielikes of the people tested as to MOR, VALUE and CAROMA.

A. Total teat date give the percent of the total number of pereone tested tho preferred elther hue 2.5 or 7.5 , value 5,6 or 7 and ahroms 4 or 8 .

B. If there hed not been a mocond choloe as to value, the reaults vould bo as show in $B$.

C. A eertaln per cent of the persons teated belleved that the difference between 2.5 or 5 and 5 or 7.5 we too great to obtain accurate resulta. This per cent is thown in C.

D. The wen tested indiceted a lightiy different preference than the vowen tested. Teat $D$ shows the preforence for men.

I. This test is similer to $B$, exeept that the deta represente only male preference.

7. Th1 test is similar to $C$, except the data represents only malo prererence.

0. This 1s a brenkiom of fomale preferences and is almilar to Teat $D$.

H. This test $1 \mathrm{~s}$ the same as reat $\mathrm{E}$, except that $1 \mathrm{t}$ is restricted to female cholces.

I. Th1s is the same es rest $F$ except that it is reotrloted to remalo cholcos. 
J. This test show a numerical breakdom of the final preferences made by the male, fomale and total is and remsie.

x. This test ahows the relative position of the colors. 
TABLE VII

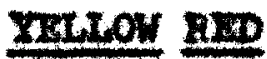

A. Totel Test Reoulte

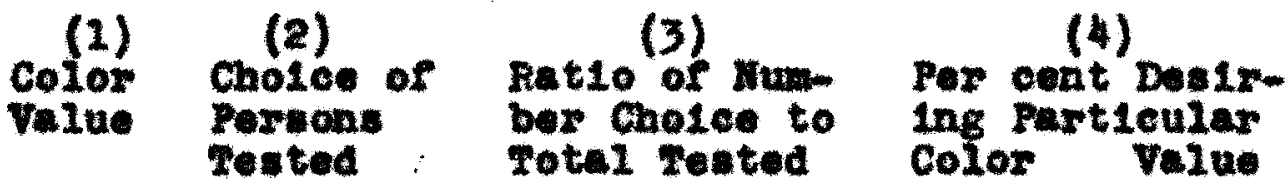

Eno

$$
\frac{2.5}{7.5}
$$

157

$157: 205$
$48: 205$

$\begin{array}{r}76.4 \\ 23.4 \\ \hline 100.0\end{array}$

Value

7
6
5

201

69

35

$\begin{array}{r:r}101 & 205 \\ 69 & 205 \\ 35 & 205\end{array}$

$\begin{array}{r}49.3 \\ 33.7 \\ 17.0 \\ \hline 100.0\end{array}$

Chrom 8

109
97

$108: 205$
$97: 205$

52.7
100.3

B. If Becond Cholce in Velue hed not been Alloved
(1)
(2)

7
5 $\quad 145$
(3)

(4)

Value

$145: 205$
$60: 205$

$$
\begin{array}{r}
70.7 \\
29.3 \\
\hline 100.0
\end{array}
$$

c. Por cent Belleving the Hue vas onmied to Excess

(1)

(2)

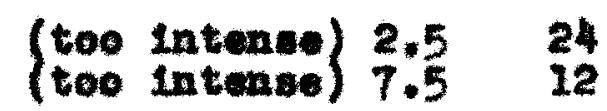

(3)

$24: 85$
$12: 85$

28.2 14.2 
TABLE VII

(eontinued)

D. Breakdora (Ea1e)

(1)

(2)

(3)

(4)

Bue

$$
2.5
$$

87
25

87: 112

$25 \cdot 112$

77.7

$\frac{22.3}{100.0}$

Velve

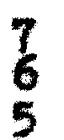

47

$47: 112$

40,112

$25 \cdot 212$

42

25

35.7

$\frac{22.3}{100.0}$

Chrow

8

74
38

$74: 112$

$\frac{66}{34}$

8. If Second Golee in ralue had not been Alloved

$\begin{array}{lllllr}\text { value } & 7 & 70 & 70: 112 & 62.5 \\ 5 & 42 & 42: 112 & \frac{37.5}{100.0}\end{array}$

7. Per oent Bellering the Eue Carried to Excese

$$
\begin{array}{lll:l}
2.5 & 6 & 6: 27 & 22.2 \\
2.5 & 6 & 3: 5 & \frac{12.2}{35.3}
\end{array}
$$




\section{TABLE VII \\ (continued)}

a. Brevedom (Domele)

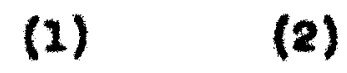

(3)

(4)

\begin{tabular}{|c|c|c|c|}
\hline Ime & $\begin{array}{l}2.5 \\
7.5\end{array}$ & $\begin{array}{l}70 \\
23\end{array}$ & $\begin{array}{l}70: 93 \\
23: 93\end{array}$ \\
\hline Ve1ue & $\begin{array}{l}7 \\
5\end{array}$ & $\begin{array}{l}54 \\
29 \\
10\end{array}$ & $\begin{array}{l:l}54 & 93 \\
29 & 93 \\
10 & 93\end{array}$ \\
\hline Chrowa & $\begin{array}{l}8 \\
4\end{array}$ & $\begin{array}{l}34 \\
59\end{array}$ & $\begin{array}{l:l}34 & 93 \\
59 & 93\end{array}$ \\
\hline
\end{tabular}

11. If second Cholce in Yalue had not been Alloved

$\begin{array}{lllll}\text { value } & 7 & 75 & 75: 93 & 80.7 \\ & 5 & 18 & 18: 93 & 19.3 \\ & & & & 100.0\end{array}$

I. Por cent Belleving the hes ㄹes Carried to Eceene

$$
\begin{array}{rrr:rr}
2.5 & 18 & 18: 58 & 31.0 \\
7.5 & 9 & 9 & 58 & -35.5
\end{array}
$$




\section{TABLE VII}

(continued)

\section{J. Card Breakdorn}

$2.5 \mathrm{~m} 7 / 8$

$2.5 \mathrm{x} 7 / 4$

$2.5 \mathrm{~m} 6 / 8$

$2.5 \times 6 / 4$

$2.5 \mathrm{~m} 5 / \mathrm{B}$

2.5 If $5 / 4$

$7.5 \times 7 / 8$

$7.5 \mathrm{~m} 7 / 4$

$7.5 \mathrm{x} 6 / 8$

$7.5 \mathrm{Im} 6 / 4$

$7.5 \mathrm{~m} 5 / 8$

$7.5 \mathrm{MR} 5 / 4$

\section{Nale}

24

12

$16_{\mathrm{H},} 12_{\mathrm{L}}$

$5 \mathrm{H}^{2} \mathrm{~L}$

7

12

8

4

$2_{L}$

$2 \mathrm{H}_{\mathrm{L}}$

5

2
Fomele

22

17

$\mathbf{2}_{\mathbf{Z}} \mathbf{l}_{\mathbf{L}}$

$16 \mathrm{H}^{4} \mathrm{z}$

3

5

4

12

1 .

$3 \mathrm{H}^{2} \mathrm{~L}$

1

1
Total

46

28

$18_{\mathrm{Z}} 13_{\mathrm{L}}$

21 IL

20

16

12

15

$3 t$

$5 \mathrm{R}^{4} \mathrm{~L}$

6

3 
BDP

Total rest:

Ine

value

Crom

$$
\begin{aligned}
& \text { (1) (2) } \\
& 5-37-37 / 134-27.6 \\
& 3-56-56 / 134-\frac{41.8}{100} \\
& 10-100 \\
& \begin{array}{r}
74.6 \\
25.4 \\
100
\end{array}
\end{aligned}
$$

If second Chotoe in value hed not been allowed:

Velue

$$
5=64
$$

Percent belleving Fue carried to exceses:

Hue

$$
\begin{aligned}
& 2.5 \\
& 7 \cdot 5=32
\end{aligned}
$$$$
\frac{23.9}{13.42}
$$

Beakdorm - Male

Hue

value

Chrome

$$
\begin{aligned}
& 2.5-40 \\
& 7.5-22
\end{aligned}
$$

$$
\begin{aligned}
& 5-17 \\
& 3-33
\end{aligned}
$$

$$
\begin{aligned}
10 & =47 \\
6 & -15
\end{aligned}
$$

$$
\begin{array}{r}
64.6 \\
35.4 \\
100
\end{array}
$$

$$
27.4
$$$$
19.35
$$

53.2

$$
\begin{array}{r}
75.8 \\
24.2 \\
700
\end{array}
$$

If second choles in relue had not been elloved:

Velue

$$
\begin{aligned}
& 5-23 \\
& 3-39
\end{aligned}
$$




\section{Table VIII (continued)}

Percent belleving fue carried to exeeses

Hue

$$
\begin{aligned}
& 2.5-21 \\
& 7.5=4
\end{aligned}
$$

33.8

6.44
-40.24

Breakdorm - Fomale

Hue

$$
\begin{aligned}
& 2.5-56 \\
& 7.5=16
\end{aligned}
$$$$
\begin{array}{r}
77.8 \\
22.2 \\
\hline 100
\end{array}
$$

Value

$$
\begin{aligned}
& 5-20 \\
& 4=29 \\
& 3=23
\end{aligned}
$$

27.8

40.3

32.9

Chroma

$$
\begin{array}{r}
10-53 \\
6=19
\end{array}
$$

If second sholes hed not been ellowed:

value

$$
\begin{array}{lr}
5=41 & 57.0 \\
3-21 & \\
& 100
\end{array}
$$

Percent belloving Bue cerried to excesses

nue

$$
\begin{aligned}
& 2.5-24 \\
& 7.5-4
\end{aligned}
$$

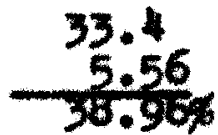

Card Ereakdoum:

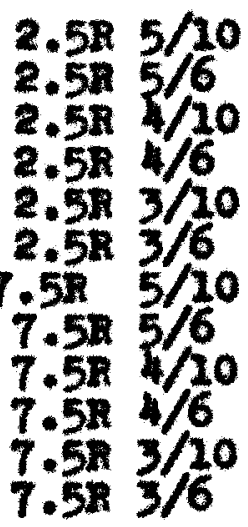

nale

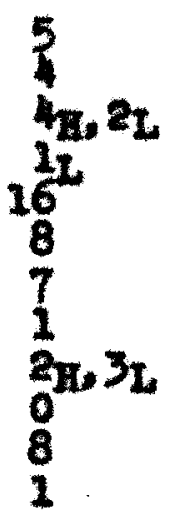

Fowal.

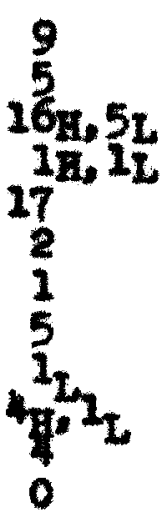

Total

14

9 $20 \mathrm{~m}, 7 \mathrm{~L}$ $3^{17} 2_{2}$ วิ

8

6

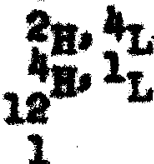




\section{TABLE IX}

\section{GRE}

rotel rents

Ine

Velue

Chroma

(1)

(3)

(4)

$$
\begin{aligned}
& 2.5-59 / 138=42.7 \% \\
& 7.5-79 / 138=\frac{57.3}{100.0}
\end{aligned}
$$

$$
\begin{aligned}
& 5=39 / 388=\begin{array}{l}
28.3 \\
6 \\
7-52 / 38 \\
47 / 38
\end{array}=\frac{37.7}{34.0} \\
& 100.0
\end{aligned}
$$

$$
6=\frac{92 / 238}{46 / 138}=\frac{66.7}{33.3}
$$

If aecond cholce in value had not been alloved:

Value

$$
\begin{aligned}
& 7-79 / 138=57.3 \\
& 5-59 / 138=\frac{42.7}{100.0}
\end{aligned}
$$

Breekcoun - Ma1e

Ine

Valne

Chrow

\section{Breakdoun - Pomale}

Ene

Value

Anroma

$$
\begin{aligned}
& 2.5-41 / 90=\frac{45.6}{54.4} \\
& 7.5-49 / 90=\frac{500}{100.0}
\end{aligned}
$$

$$
\begin{aligned}
& 5=28 / 90=31.1 \\
& 6=34 / 900=37.8 \\
& 7-28 / 90=\frac{31.1}{100.0}
\end{aligned}
$$

$$
\begin{aligned}
& 2-70 / 90=\frac{77.8}{22.2} \\
& 6-20 / 90=\frac{220.0}{100.0}
\end{aligned}
$$




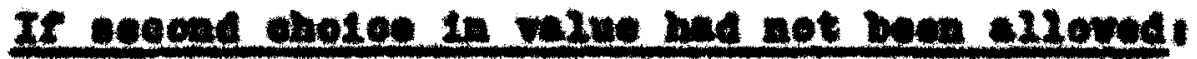

$$
\text { value } \quad \begin{aligned}
& (1) \\
& 7 \\
& 5-29 / 78
\end{aligned} \frac{-60.4}{-39.6}
$$

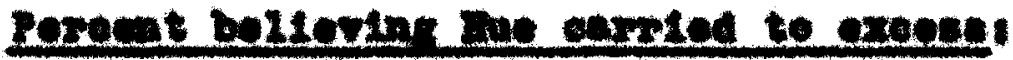

Ino

$$
\frac{2.5}{7.5}=19 / 48=\frac{18.75}{58.65}
$$

\section{cana Dresclow:}

$$
\text { mire Dowale gotal }
$$
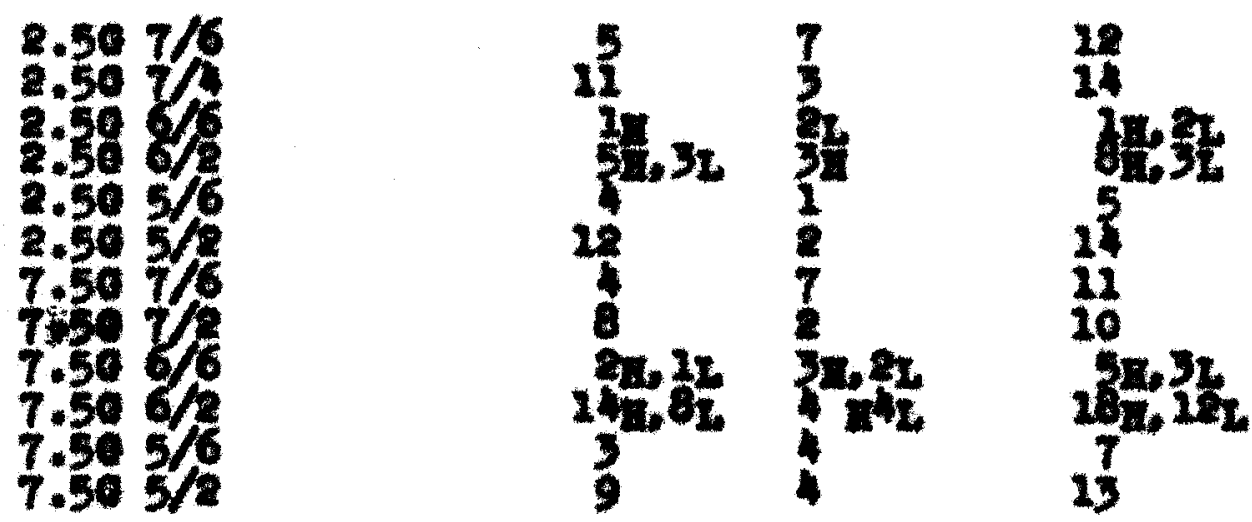


\section{OBSERVATIOH}

some observere reverted thonselves in velue on cholce the from their selection on cholce \#2. This was because choloe 72 we consldered too extreme. The seme vas true of observers reversing the selection of hue on cholce \#5.

All observers tend to choose a color that w112 look best on aone perticular object. Men think of peint, and woman, of clothes.

Almost everyone elaining color blindness could distinguish a difference in any two colors, therefore reoults of tests vere not materially chenged.

From the rindings of one or two colors it is

1mposelble to forecast the reanlte for a third color.

III: In all casel the bluer hue ves preforred, but to a greater extent by vomon, especialiy in the ouse of green. In the funsell system, the closer the color approaches blue, the groater the tendeney to cansider the bluer hue cholve exceasive.

valus: In all cases vomen prefer their colors to be brighter then do men. Men prefer derk reda, modium green and light yolion roda.

crroki, Hen 11ke greens to be quite grey, but they 11ke yellow reds to be vel1-saturated. Wowen are just the opposite. Both won and vomen, hovever, want reda of strong chroma. 


\section{Teble $x$

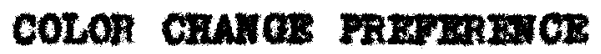

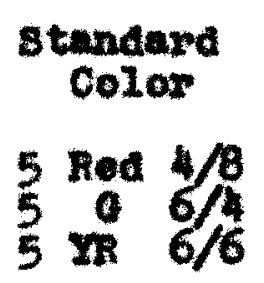

Preference

Vario onrow

Dark strong

Modiun Woak

Hight strong
Denele Preference

Bluer Medim strong Bluer Light estrong Redder Light weak -rairiy stroag

\section{PROJECTIOA}

Further study of odditional dark colors and tinte 1. noceseary to determine color proforwee. These findings vil be applled to representative color cards, which vill then be tested as proof of the theory. Part II of this thesile Is concerned vith only a portion of this etudy and on the coupletion of the study, it will be incorporated into the final results. 


\section{Exturegara}

\section{$\operatorname{lng} 2$}

1. Euter, V., Mantek., 26, 413. (2905).

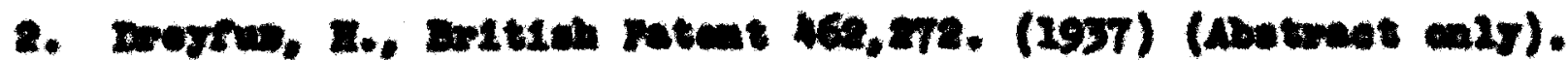

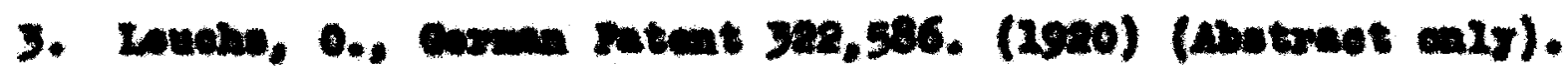

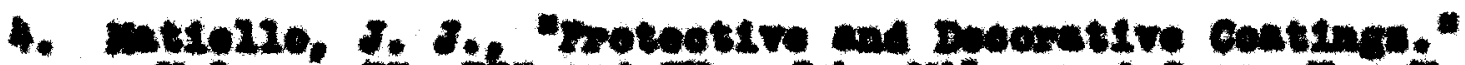

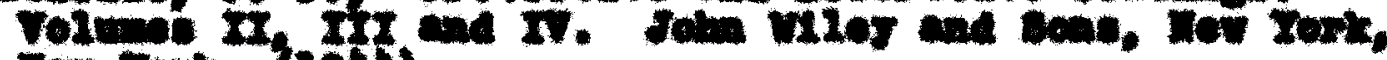
now row. $(29+4)$.

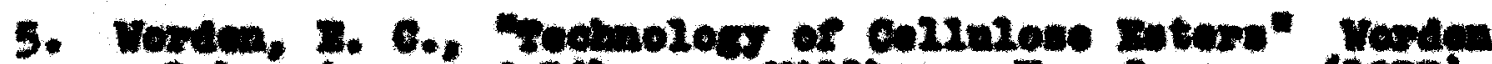

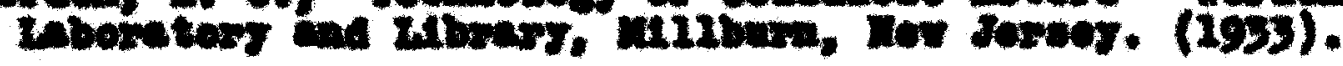

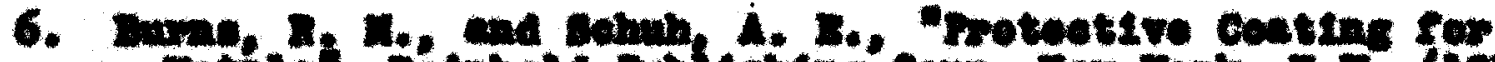

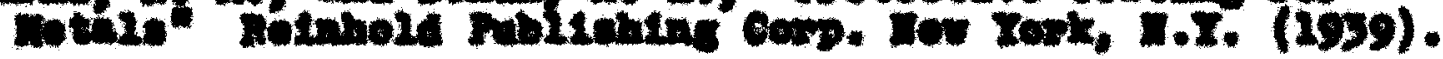

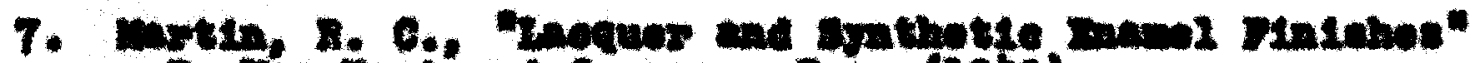

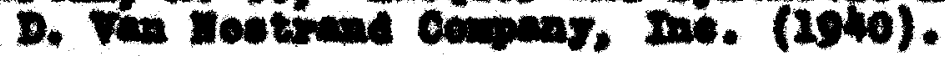

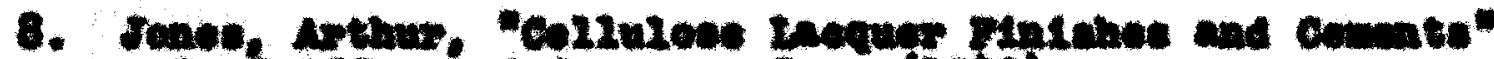

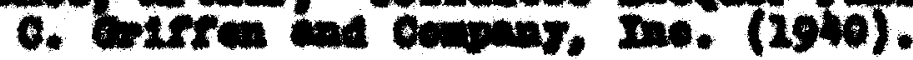

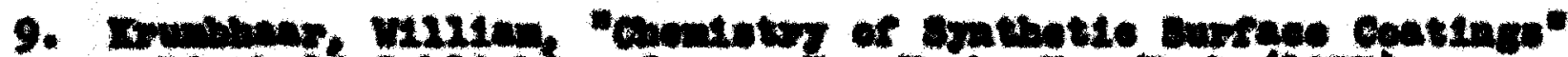

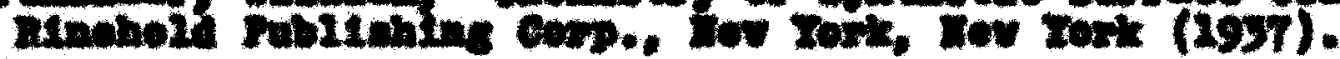

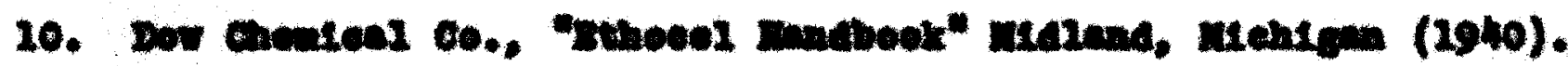

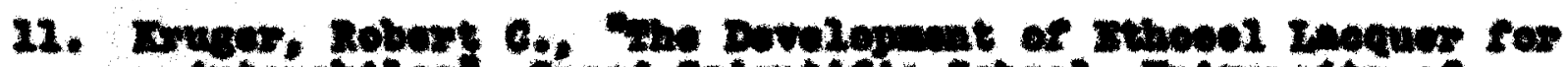

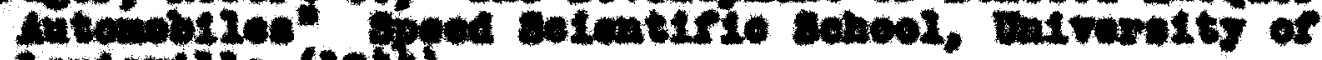
toatevisio (1967).

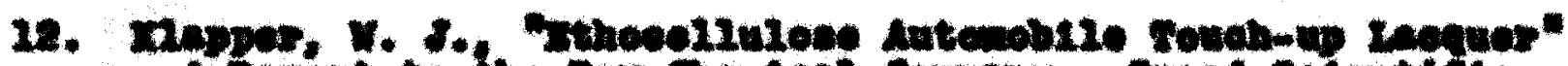

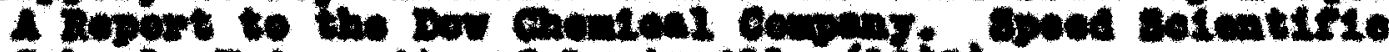

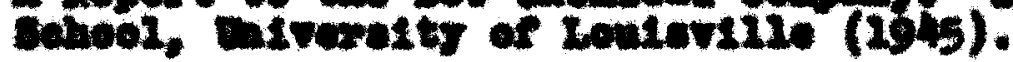

\section{We $\mathbf{x}$}

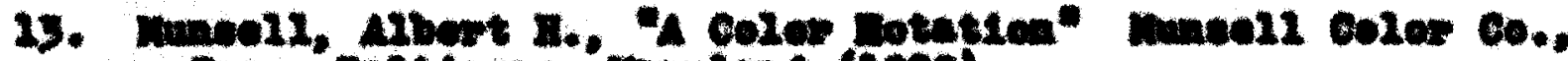

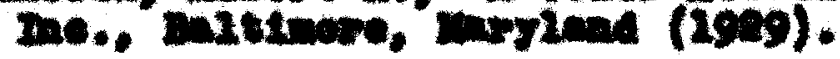

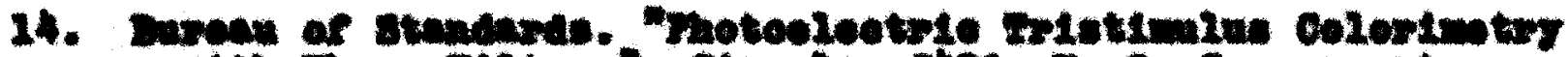

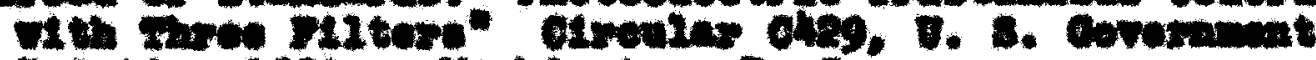
Finting orrtes, Mulugtea, D. C. 


\section{VTR}

Thadeus sndrev Peake, Jr. was born in Loulsville, Kentucky on Detober 21, 1919, con of Thaddeus Andrey and Mary Blisabeth Peake. He recelved his primary education at stephen Foster school and at shamee school. HI high school educetion vas completed at Louidvilie Hie High School and h1. college vork vas done at the speed selent1fio Bchool of the University of Loulaville. He secelved hie Buchelor of Chemical Ingtneering Degree in June of 1941. He at once ontered the Graduate Sahool in purault of his Meater of Arte Degree in Chomical magineering; but when ver vas declared on Gerweng and Japan Docember 7,1941 , he enzisted in the onited states neval Academy for midohlpwen training. on september 8, 1942, he recelved bis comisstion as Ensign, Engineer (Volunteer) Genural, V.s.I.R. The folloving Havy Courses vere completed by bim: (1) Bavel wine varfare Course, Yorktovn, Virginia, (2) Mine Disposal Course, wavy rerd, Wahington, D.C. (3) Deep soe Diving Couree, Hevy Yard, Wahington, D.C. (4) High Voltage X-Rag Courso, Maval Powder Factory, mulane Head, Margland. On completion of the above courses, he vas ausilfled utne Disposel offleer, 
second Clase Deep Sea Diver and Operator of High Voltage $x$-Rey mite for mxplosive mvestigation.

Mr. Peake vas married to Marthe Jane sohott of Loulevi11e, Kentuokg Apr11 8, 1943.

Inwodictels, upon completing the above courses, be was ordered to the Explosive Inventigation Laboratory, Port Torneond; Nahington as offleer-in-Charge. After one and one-helf year's duty at Port Towneend, he vas ordered to the Mobile Exploalve mvestigation Dalt Mo. I at Pearl Harbor, T.H. While he vas attached to the Hoblie Explosive Investigation mit 44 , he took sctive part in the wine DIspoesl Operations of Oxtnave and also in the inftial phases of the occupation of Japan. While he we in Japan, he vas atteched to the raval Pechnteal Miosion to Jepen in charge or wine D1sposal Inte111gence. On Fobruery 25, 1946, he wes placed on ineetive Eaval Daty with the rank of Ifeutenant, which title be recelved January 11, 1945.

Mr. Peake reentered the Oredunte Bohool ImmediateIy to complete his master of Arte Dogree in Choulcal meineerIng at the mivereity of Louleville. 